\title{
EL PATIO DEL CRUCERO DE LOS REALES ALCÁZARES DE SEVILLA
}

\author{
Antonio Almagro \\ CSIC - Granada
}

El presente artículo es resultado, en gran medida, de los trabajos de levantamiento planimétrico de los Reales Alcázares de Sevilla, realizados por encargo del Patronato del Real Alcázar a la Escuela de Estudios Árabes de Granada (CSIC). Como en otras ocasiones ya hemos sostenido, el levantamiento arquitectónico debe entenderse como una forma de análisis y aproximación al conocimiento de los edificios que en ningún modo puede ser sustituido por otro tipo de investigación. La información que puede y debería generarse siempre durante el proceso de medición y dibujo, que por necesidad tiene que corresponder a un análisis exhaustivo de la propia materialidad de las estructuras arquitectónicas, es siempre muy superior a la que luego puede quedar plasmada en los dibujos finales. No es por tanto, y como norma general, el método más recomendable encomendar a terceros la realización de tales trabajos por parte de quienes tienen la responsabilidad del estudio, la tutela y la conservación de los edificios, pues debieran ser ellos las personas que mejor los conocieran, poniendo para ello los medios adecuados, cual es la realización de los levantamientos. Bien es cierto que la complejidad metodológica y el recurso muchas veces necesario a técnicas de medición, por desgracia aún poco generalizadas, como pueda ser la fotogrametría, obliga en ocasiones a recurrir a otros técnicos, que en muchos casos carecen de la formación adecuada para poder realizar simultáneamente un análisis completo de la realidad arquitectónica que se está estudiando o restaurando. Sirva pues este artículo, aparte de para dar a conocer informaciones de interés respecto a una parte sustancial de los Alcázares de Sevilla, como ejemplo metodológico del modo de abordar el estudio de nuestro patrimonio histórico arquitectónico.

El palacio, primero islámico y luego cristiano, que se articula en torno al llamado Patio del Crucero, ha sido objeto de atención por diversos investigadores, quienes han tratado de describirlo literariamente, aunque en general sin llegar a analizar con detenimiento su estructura y, sobre todo, sin establecer con precisión una planta siquiera hipotética. Las primeras indicaciones expresas de su posible ascendencia islámica se deben a L. Torres Balbás (1958: 179) quien publicó un croquis realizado por F. Hernández. Más tarde, el tema ha sido reto- 
mado por R. Manzano (1991: 33-36) que con posterioridad ha realizado dos estudios algo más extensos (Manzano 1995a: 342-3, 1995b: 109-111) La planimetría hasta ahora disponible, aparte del croquis de F. Hernández, se reduce a la realizada por R. Manzano con motivo de su parcial excavación y restauración, publicada por A. Marín (1990: 60) y una serie de planos, dibujados al parecer por alumnos y publicados por R. Cómez (1974: 101, 115, 133). Estos planos parecen estar basados en la planta de Manzano, aunque en las hipótesis de reconstrucción presentan numerosos errores e imprecisiones. R. Cómez ha vuelto a tratar del tema en dos trabajos posteriores (1996a, 1996b), aunque sin identificar con claridad la obra islámica y la gótica. En la planta de Manzano sólo se representan dos fases constructivas, considerando todas las galerías del crucero como contemporáneas de los pórticos periféricos, aunque en sus descripciones ya plantea la diacronía de las estructuras del crucero y las de los pórticos laterales, pero suponiéndolas todas almohades. Posteriormente ha publicado dos plantas esquemáticas del alcázar (1995a: 333, 1995b: 106) en que aparece dibujado este patio con un intento de representar la planta del nivel del jardín y la de los salones en cada mitad. Sin embargo, en estos esquemas no hace distinción alguna entre las estructuras islámicas y las góticas. Aun cuando nuestro estudio pretende abordar el tema con mayor detalle y profundidad, hemos de reconocer las limitaciones que impone la situación actual de este patio (fig. 1,2) que fue radicalmente transformado tras el terremoto de Lisboa de 1755, y que impide conocer muchos de sus detalles que se conservan bajo las tierras del jardín hoy plantado 4,70 m por encima de su nivel original. No obstante, es previsible que intervenciones arqueológicas, siquiera parciales, sobre todo en los paramentos de las zonas inferiores, vayan en el futuro proporcionándonos más información. Por esta razón se debe entender que muchas de las hipótesis gráficas que incluye este trabajo son plausibles solamente en sus rasgos generales, es decir, en la descripción de los espacios y volúmenes, mientras que si hemos dibujado en muchos casos detalles de los que no existe ninguna certeza, ha sido sólo con la finalidad de facilitar al lector la comprensión, siquiera a nivel de evocación, de la conformación espacial que en los distintos momentos históricos tuvo este singular conjunto.

\section{El PALACIO ISLÁMICO}

El llamado Patio del Crucero es una de las diversas estructuras que integran el conjunto de los Reales Alcázares de Sevilla. Este conjunto palatino, el más 
antiguo de las residencias reales de toda Europa aún en uso, es a la vez el fruto de una noción de residencia áulica de raíz oriental y de la evolución y superposición de estructuras de distintas épocas y que por tanto atienden a modos distintos de concebir un palacio. El sistema de agregación de elementos que constituye la base compositiva del conjunto áulico sevillano ha dado lugar a una estructura compleja de edificaciones que, originadas como elementos cuasi-autónomos, han sufrido posteriormente procesos integradores que trataban de lograr una organización unitaria. Por esta causa, cada uno de los elementos que inicialmente se concibieron como células independientes del conjunto palatino puede y debe ser analizado individualmente sin perjuicio de su estudio en relación con todo el conjunto.

El Cuarto del Crucero era una de las distintas unidades residenciales con que contaba la zona interna del Alcázar sevillano al menos en época almohade. Esta área interna, que posiblemente corresponde al recinto de la primitiva Dār al-Imāra, ordenada construir por 'Abd al-Raḥmān III, aunque quizá ampliada ya en época 'abbādí, puede hoy identificarse por el trazado de sus murallas construidas con grandes sillares, a diferencia de las estructuras de época almohade que se levantaron con tapia o ladrillo. El recinto tenía forma trapecial con su base mayor en el costado norte, dando a la plaza del Triunfo y a la calle Romero Morube mientras la base menor debió estar situada en el actual límite meridional de los palacios que marca el inicio de las zonas ajardinadas. No se ha podido reconocer, hasta el presente, ningún elemento que permita asegurar que este recinto de la Dār al-Imāra primitiva se cerraba en algún sitio cercano al lado meridional del Patio de Banderas, sobre la base de suponerle una planta cercana al cuadrado (Jiménez 1981: 15-16), mientras que, como tendremos ocasión de comentar, sí existen elementos de muralla que pueden atribuirse a este recinto al sur de esa supuesta línea de cierre. Las razones que motivaron la acusada irregularidad de la planta de esta estructura militar cuya forma y dimensiones se alejan notablemente de la que se ha considerado siempre como su más inmediato paralelo, la de la alcazaba de Mérida, pudieron estar relacionadas con la estructura urbana preexistente. Lo cierto es que ni el lado oriental ni el occidental poseen un recorrido rectilíneo además de presentar una acusada convergencia acentuada sobre todo en la zona media del lado este.

Dentro de dicho recinto resultan más o menos reconocibles como estructuras residenciales islámicas, este conjunto que ahora analizamos, el llamado Patio o Cuarto del Yeso y la vivienda cuyos restos se conservan dentro de la casa n. $^{\circ} 3$ del Patio de Banderas, también conocida como casa Toro-Buiza (Manzano 1995b: 117), si bien el resto del parcelario ha debido mantener la 
estructura y otros restos de la edificación desde el período islámico. De todos ellos, el Patio del Crucero (Fig. 3) es el más meridional y el de mayor tamaño. Las primitivas dimensiones de este edificio residencial no resultan fáciles de precisar debido a los procesos de agregación y sustitución que ha sufrido. Sin embargo, sobre la hipótesis que después expondremos, podemos avanzar que estuvo inscrito en un rectángulo de aproximadamente $68 \times 45 \mathrm{~m}$, orientado con su eje mayor en dirección NO-SE con un giro hacia el oeste respecto a la dirección norte de $36^{\circ}$. Por razones de comodidad y de mayor simplicidad, consideraremos en lo sucesivo a este eje como la dirección norte-sur para todas nuestras descripciones.

Aparte de la originalidad que en su ordenamiento presentaba este edificio, debemos resaltar que se trata del palacio con disposición de patio que cuenta con mayores dimensiones de los que conocemos en al-Andalus, por encima del palacio de Comares que sólo tiene 54 por $32 \mathrm{~m}$ (excluyendo la torre de Comares). Sólo le superaría el supuesto patio de crucero de época mardanīší del convento de Santa Clara la Real de Murcia (Navarro 1998: 104), aunque nos inclinamos por pensar que los restos allí descubiertos debieron más bien pertenecer a un gran jardín de crucero con un pabellón central y quizá otros periféricos, más que a un patio de un edificio propiamente dicho.

Diversos elementos hacen suponer que dentro del escasísimo relieve que presenta el terreno en la ciudad de Sevilla, en la zona en que se construyó este palacio sevillano se producía un desnivel que fue aprovechado para disponer la particular organización espacial de este conjunto. Desconocemos, no obstante, si con el fin de establecer un patio rehundido tal y como estuvo durante un largo período antes de que fuera rellenado y enrasado al nivel de las estructuras superiores, se realizaron desmontes o terraplenados. Lo cierto es que el rectángulo del patio, con unas dimensiones de 47,40 x 34,40 m, se encontraba situado a un nivel $4,70 \mathrm{~m}$ por debajo del nivel principal de su acceso y de sus salones (figs. 4-6). Este nivel resulta incluso inferior al de los actuales jardines que se extienden al sur de los palacios aunque pudo quizá corresponder al primitivo suelo natural si suponemos que se ha producido un proceso de rellenado y aumento de nivel en todo el entorno, por causa tanto de los aluviones del río como del aumento artificial de la cota del terreno como medio de defenderse de las inundaciones fluviales.

Así, este palacio que podemos considerar organizado en un doble nivel, debió de estar formado en su zona alta por un gran patio rectangular flanqueado por dos salones de planta oblonga y proporción muy alargada, dispuestos en los testeros norte y sur, es decir, los dos más cortos (fig. 3). Es más que posi- 
ble que en los laterales largos contara también con crujías, aunque nada podemos asegurar al respecto. En el lado occidental, entre el muro del patio y la muralla, quedaba un espacio de planta triangular que pudo estar ocupado por habitaciones con acceso desde el patio o haber servido de elemento separador de la muralla inmediata. En el lado opuesto debió existir otra crujía, que tendría sin duda planta regular, pero de cuyo muro exterior sólo podemos conjeturar que coincidiera con un muro interior que se conserva en el cuerpo actual de edificación de ese lado.

Conocemos las dimensiones del patio gracias a que se han conservado sus muros perimetrales en el nivel inferior, así como en parte del lado occidental de la planta baja. Aunque los salones propiamente dichos han desaparecido, puede identificarse su situación y dimensiones por los límites fosilizados que han pervivido en las transformaciones posteriores, así como por algunas referencias documentales. El salón meridional debió corresponder básicamente con el que hoy conocemos como Salón de los Tapices (fig. 6), aunque con una apreciable menor anchura. Su longitud, pues, coincidiría con la actual de ese salón aunque contaría sin duda con las correspondientes alhanías en sus extremos cuya dimensión quedaría incluida dentro de la marcada por el salón posterior. No creemos que el muro sur de este salón coincidiera con la muralla meridional de la Dār al-Imāra, sino que pensamos que es más probable que existiera un pequeño corredor o paso de servicio entre aquél y ésta. Dicha muralla estaría situada por tanto muy próxima al muro exterior meridional del palacio gótico y vendría a cerrarse contra la torre de ángulo del callejón del Agua, lugar éste en el que convergen, en lo que sería ángulo de la Dār al-Imāra, la muralla exterior de la ciudad que se dirige hacia la puerta de la Carne y la almohade que encerraba la huerta del alcázar.

A este respecto, debemos indicar que suele ser bastante habitual en la arquitectura hispanomusulmana respetar las murallas y no adosar a ellas edificios residenciales. Salvo en el caso de los palacios de Comares y del Partal de la Alhambra que se asoman y montan sobre la muralla, aunque manteniendo la servidumbre militar de la ronda mediante pasadizos inferiores, suele ser lo normal dejar un paso o una separación de respeto a lo largo de las murallas (Bermúdez 1992: 160, Almagro 1996: 211, Almagro 1998: 413). Este pasadizo de respeto pudo haberse dejado igualmente en el lado occidental, aunque aquí la muralla ya no daba al exterior, sino a otro recinto ampliado posiblemente en época 'abbādí (Manzano 1995b: 104). Este salón meridional tendría su muro sur coincidiendo aproximadamente con el que en la actualidad separa el Salón de Tapices del Salón Gótico, mientras que el muro norte debía corresponder a la 
alineación de un muro conservado por debajo de la cota del primer salón mencionado. Dicho muro se encuentra a unos 2,50 m más al sur de la fachada actual del Salón de Tapices, y puede observarse en la zona inferior, en la ampliación que se ha practicado en el hueco de la escalera que suponemos comunicaba los dos niveles. Tendría pues este salón una anchura de 5,20 m y una longitud de $34,38 \mathrm{~m}$, incluyendo las alhanías y suponiendo que su extremo occidental no estuviera retranqueado para dejar también aquí un pasaje junto a la muralla.

Este salón contaría con un pórtico como es habitual en la arquitectura doméstica andalusí, que se encontraría situado en donde hoy se levanta el actual pórtico construido por Sebastián van der Borcht, aunque desplazado hacia el sur $3,90 \mathrm{~m}$. Como ya indicaremos, todo hace pensar que a este pórtico no se podía acceder por su frente, ya que el suelo del patio quedaba a una cota 4,70 $\mathrm{m}$ por debajo de la suya (fig. 5). El acceso al mismo se haría, bien por su extremo oriental a través de la crujía que hubo en ese lado o bien por los andenes laterales que recorrían ambos lados mayores del patio sobre una estructura porticada de la que hablaremos al tratar del nivel inferior. Como más adelante tendremos ocasión de comentar, ningún resto identificable nos permite asegurar actualmente que el patio primitivo contó con un andén central al nivel superior comunicando los dos pórticos y menos aún con otro andén similar dispuesto en dirección perpendicular y ubicado en su eje menor formando crucero. Tal disposición, que existió durante un largo período de la historia del patio, parece en todo caso haber sido introducida con las transformaciones de la segunda mitad del siglo XIII. Sólo podemos apuntar como hipótesis la posible existencia de una escalera para descender al jardín coincidiendo con el arco central del pórtico.

En el lado septentrional hubo otro salón del que quedan sobre todo testimonios documentales. Debió ser, por su orientación hacia mediodía, el principal del palacio islámico. Se le conocía como Cuarto del Maestre a causa de la tradición según la cual, en una de sus alcobas, Pedro I dio muerte a su hermanastro don Fadrique, Maestre de Santiago. En el siglo Xvi se decía aún que se conservaba la mancha dejada por la sangre del Maestre (Marín 1990: 252). Este salón que debía ser igualmente estrecho y alargado, se describe en 1568 dándole las dimensiones de 51,5 pies de largo por 14,5 de ancho. Se dice además de él que su muro perimetral estaba formado por un doble muro con un corredor interior de 1 vara $(83,5 \mathrm{~cm})$ de ancho y que tenía una altura de 10 tapias $(8 \mathrm{~m}$ aprox.). Se dice igualmente que disponía de un pórtico con pilares de ladrillo que se recomienda en esa fecha que sean sustituidos por columnas de mármol (Gestoso 1889: 329, Marín 1990: 253). La estructura del salón debió ser fuerte- 
mente transformada a finales del siglo XVI. En el plano conservado en el Archivo de Simancas fechado hacia 1608 (Marín 1990: 356) el salón aparece agrandado respecto a las medidas descritas en 1568 , pero aún se aprecia la existencia del pórtico. Se propone en ese plano la construcción de una escalera de tipo imperial precisamente en la zona en que debía estar situada la alcoba con la sangre del Maestre. En el plano dibujado por Sebastián van der Borcht en 1759 (Manzano 1983: 50, Marín 1995: 249), el salón resulta ya irreconocible e incluso su pórtico ha desaparecido totalmente al construirse a su lado el paso hoy existente entre el Apeadero y el Patio de la Montería y haberse ocupado el espacio del salón con distintas construcciones y estancias.

De todos estos datos podemos conjeturar que el salón debió contar con una longitud total de $34,40 \mathrm{~m}$, equivalente a la anchura del patio. Dentro de esta longitud debemos considerar incluidas las dos alcobas o alhanías de las que la occidental era, según la tradición, aquella en la que don Pedro había dado muerte a su hermano, mientras la oriental fue transformada en capilla en un momento desconocido, anterior a la descripción de 1568. La anchura del salón, según dicha descripción, era de 4,05 m mientras la longitud que se nos da en ese momento de 14,35 m parece indicar que la sala primitiva había sido subdividida posteriormente. De su pórtico, aunque nos falta información, podemos intentar reconstruirlo sobre la hipótesis de que guardara relación con el conservado en el nivel inferior. En los extremos habría dos arcos o puertas pequeñas de acceso a los andenes altos laterales, mientras que en el centro habría un arco de mayor tamaño. Puesto que el pórtico inferior tiene un número elevado de huecos ( 6 en cada lado) y de escasa luz, puede pensarse que cada dos arcos inferiores coincidieran con uno del nivel superior. De este modo, resulta una composición totalmente concordante con otras coetáneas y en especial con la del Patio del Yeso. Un gran arco central sobre gruesos pilares quedaría flanqueado por tres arcos menores a cada lado que pudieron estar sustentados sobre columnas. En este caso se añadirían las pequeñas puertas en los extremos para acceso a los andenes laterales que comunicaban ambos extremos del patio. Del origen de esta composición, R. Manzano ha apuntado su posible inspiración en la disposición de las arquerías centrales del salón de la Dār al-Ŷund de Madīnat al-Zahrā' (Manzano 1995a: 318, 344). Otra posible ordenación de este pórtico podría guardar relación con la que presenta el frente norte del llamado Patio de Contratación (Manzano 1995a: 347-9, fig. 241-5). En este caso, el arco central está acompañado por una alternancia de pilares y columnas de tal modo que entre los pilares quedan vanos geminados. De seguir esta composición, sobre cada pilar del pórtico bajo habría un soporte del superior, alternando pilares y 
columnas. De todos modos, debemos resaltar que en ambos casos los arcos daban al vacío del jardín, situado en un nivel inferior, aunque es posible que del arco central arrancara una escalera de bajada a dicho nivel. La anchura del corredor de este pórtico era de 3,50 m.

El salón septentrional se conectó a finales del siglo Xvi con la sala sur del Patio del Yeso, abriendo un paso por el eje del salón que coincidía con la alhanía oriental de la otra sala. Esta apertura supuso romper el esquema típico del palacio islámico con una operación muy semejante a las practicadas en otros casos como en las casas moriscas del Albayzín de Granada, en donde se abrieron comunicaciones directas con el patio a través de una de las salas principales (Almagro, Orihuela 1997: 23).

La entrada principal al Patio del Crucero se debía realizar por el extremo oriental del pórtico de este lado norte. Por este punto se comunicaría con la entrada ordinaria de los palacios desde el patio de Banderas que a comienzos del siglo XVII fue transformada con la construcción del actual Apeadero. Por el lado occidental pudo haber tenido comunicación con el patio de la Montería, aunque en esta zona la muralla separaba el interior del primitivo recinto de la Dār al-Imāra del recinto de ampliación de época 'abbādí. Esta muralla parece que había sido parcialmente derribada a mediados del siglo XVI, pues se habla en varias ocasiones de la construcción de un muro de separación entre el patio del Crucero y el de la Montería (Gestoso 1889: 332, Marín 1990: 242). Este muro debía formar parte de una nueva crujía que sustituiría tanto a la muralla como al muro de cerramiento del patio y que pretendía regularizar esta zona intermedia cruzada en diagonal por la muralla. Esta crujía sería finalmente construida en la remodelación realizada por Sebastián van der Borcht.

Apenas nada más puede decirse de la estructura de este palacio referente a la planta baja en que se encontraban sus salones. De hecho, sólo puede suponerse perteneciente a su primitiva construcción un trozo del muro occidental en su zona más meridional. Desde la esquina del ángulo suroeste del patio hasta la primera puerta situada más al norte en este muro, la pared de la planta baja está construida de tapial, como puede verse en la cara interna, dentro de un espacio triangular que queda entre los restos de la muralla de la Dār al-Imāra y el muro en cuestión. Ambos muros sólo se conservan hasta la altura del forjado de la planta alta, si bien la muralla aún se prolonga hasta la línea de la fachada del palacio de don Pedro, en donde hay indicios de la existencia de una torre. El muro de tapial ya mencionado se encuentra en su cara exterior revocado y quizá forrado de ladrillo presentando un aspecto en todo semejante a los demás del patio, con la forma y disposición de huecos realizada en el siglo XVIII. 
Los restos materiales más importantes correspondientes al primer período de este palacio se encuentran en lo que hoy son subterráneos del patio actual y que primigeniamente fue el jardín y sus pórticos situados a 4,70 m por debajo de la cota de los salones. Existen en esta zona inferior numerosas estructuras correspondientes a diversas épocas, algunas de datación absoluta problemática, aunque sí puede establecerse una cronología relativa mediante el análisis de las adhesiones y superposiciones. Básicamente se pueden distinguir tres fases constructivas. Las estructuras más antiguas no tienen datación absoluta. Sólo podemos aducir que son anteriores a las que presumimos de época gótica a juzgar por las modificaciones que estas últimas ocasionaron en las anteriores. Las podemos por tanto suponer como islámicas aunque sin que se pueda asegurar si son almohades o anteriores ante la falta de elementos estilísticamente bien definidos.

Por lo que hoy puede vislumbrarse, la estructura de este primer patio en su nivel inferior estuvo formada por unos pórticos perimetrales que cobijaban un andén cubierto que estaba acompañado, al parecer, por otro en la zona descubierta. Por las razones que luego apuntaremos, parece que esta zona descubierta estuvo ocupada por varios arriates cuya disposición no conocemos con exactitud, pero que intentaremos reconstruir. Como ya dijimos anteriormente, nada permite asegurar que hubiera otras estructuras arquitectónicas dentro del patio fuera de los pórticos perimetrales. De éstos se han conservado los que corren a lo largo de los dos lados mayores y el del lado septentrional, todos ellos casi en su integridad, salvo lo que se vio afectado por las actuaciones de la segunda mitad del siglo XIII. Los pórticos laterales son de una gran sencillez (lám. 3). Se soportan con pilares cruciformes cuyo núcleo tiene las dimensiones de 48 por $48 \mathrm{~cm}$ con elementos salientes en las cuatro caras de $14 \mathrm{~cm}$. Sobre estos pilares se apoyan arcos de escasísimo apuntamiento, casi cercanos al medio punto y que presentan la particularidad de que sus impostas se sitúan por encima de la altura de los centros, teniendo apariencia de arcos rebajados. Estas impostas están marcadas además por un ligero saliente respecto a la jamba del pilar del que arrancan las curvas de los arcos aunque en muchos casos aparecen alteradas como si hubieran tenido algún elemento decorativo luego arrancado. La cara exterior de estos pórticos se sitúa a $1,70 \mathrm{~m}$ de la pared perimetral de cierre del patio. Queda por tanto entre los pilares y el muro un corredor de tan solo $1,08 \mathrm{~m}$ de anchura. En su cara externa, los arcos quedan recercados por un alfiz que se forma con el resalte exterior del pilar cruciforme. Sobre la base de lo hoy visible, no podemos saber si estos arcos tuvieron primitivamente el aspecto que hoy presentan, sin impostas ni forma de herradura, o si este aspecto es más 
bien consecuencia de una reforma posterior a la que posiblemente corresponde el enlucido que hoy presentan, que sin duda tiene que ser al menos contemporáneo, si no posterior, a la obra gótica, ya que recubre y uniformiza las modificaciones que se hicieron en ese momento. De la reparación de estos revocos así como de su ornamentación pictórica tenemos referencias documentales entre 1577 y 1579 (Marín 1990: 288), lo que permite asegurar también que, por lo menos parcialmente, se han realizado refacciones posteriores en estos revestimientos.

Estos pórticos laterales estarían formados por 12 arcos cada uno de $3,15 \mathrm{~m}$ de luz, según la hipótesis que mantenemos. El corredor del pórtico se cubre con bóvedas de directriz perpendicular al pórtico y por tanto de generatriz paralela a los arcos, de modo que no producen empujes normales al mismo que pudieran provocar su vuelco hacia el patio. El apoyo de estas bóvedas se realiza en arcos que cabalgan entre los pilares y el muro, a baja altura, de forma que su empuje tiene su aplicación sobre el pilar muy cerca de la base. No obstante, los actuales arquillos no pueden ser los originales ya que se apoyan en recrecidos claramente visibles adosados al brazo de la cruz de los pilares que se proyecta hacia el interior del pórtico y presentan formas muy irregulares rematadas por medio del revoco.

La afirmación, anteriormente expuesta, de que el patio primitivo no tuvo andén transversal a la cota del nivel superior, se basa en la observación de que originalmente estos pórticos laterales no tuvieron solución de continuidad y menos en donde después se situó el andén que forma crucero. Para construir éste y dotarle de paso inferior al nivel del jardín, hubo que eliminar el pilar que coincidía en el eje transversal, reduciendo la luz de los dos arcos contiguos con el fin de dejar espacio para los pilares del andén del crucero. Además, para dar acceso a la galería inferior se dejó un arquillo coincidiendo exactamente con el pilar primitivo, que tuvo que ser cercenado en su parte inferior. Todo esto resulta hoy visible por el interior del pórtico, en donde se aprecian los dos arcos primitivos y los realizados posteriormente con menor luz y altura, así como los recrecidos de los pilares, y la ruptura del central para abrir el paso. Todo está muy enmascarado por el enlucido posterior a esta reforma y sobre todo por el tapiado de toda la arquería que se realizó en el siglo XVIII para proceder a rellenar los cuatro grandes cuarteles del jardín hasta la cota del nivel superior. Aunque volveremos sobre este tema más adelante, sí debemos remarcar que la disposición de los pilares y arcos de los pórticos laterales no guarda relación alguna con los del pórtico y andén central del crucero, lo que constituye un dato más para asegurar su diacronía. 
El pórtico del lado norte guarda sintonía con los que acabamos de describir, aunque presenta notables diferencias (lám. 1, fig. 5). Este pórtico no servía para sostener un simple andén lateral, sino que soportaba el pórtico superior que precedía a la sala ya descrita del nivel de planta baja. La distancia desde la cara exterior de los arcos hasta el muro de cierre del patio en este caso es de 3,55 m. Aunque la disposición de arcos y bóvedas es semejante a la ya descrita, aquí se colocaron los arcos con una luz menor, $1,18 \mathrm{~m}$, y se reforzaron los pilares prolongando el brazo que se extiende hacia el muro perimetral hasta sólo dejar un paso de 1,80 m (lám. 2). Los arcos en este caso son de medio punto pero tienen un ritmo más continuo, aunque en su cara exterior presentan la misma organización que los ya descritos de las galerías laterales, con el recuadro configurado por el saliente exterior de los pilares formando un alfiz.

La zona central de este pórtico presenta algunos interrogantes, ya que ha sido muy alterado por el enteste de la galería gótica del andén central y por la formación de la fuente de grutescos realizada en época renacentista (Marín 1990: 287) para alimentar la alberca central del patio situada bajo el andén. Ante todo, hay que decir que este pórtico presentaba un entrante por debajo de la sala norte del patio, a modo de pequeña gruta, que se cubre con bóvedas de arista. Éstas se prolongan hacia el patio hasta quedar interrumpidas por la pared de rocalla de la fuente y por las bóvedas que soportan el andén central. No es pues posible saber cómo se resolvía en la primera fase del patio esta zona central.

En la zona inmediata a este pórtico septentrional, tanto en el lado oriental como en el occidental, se ha conservado el andén exterior que bordeaba los arriates. Del andén perimetral parte otro hacia el sur que queda enseguida interrumpido por la cimentación del pasaje que comunica el Apeadero con el Patio de la Montería, realizado por Sebastián van der Borcht, aunque en el lado occidental también aparece dentro del subsuelo de este paso. Parece por tanto deducirse que cada cuartel del crucero se subdividía en dos o, lo que es más probable, en cuatro arriates que seguramente formarían cruceros secundarios. Merece destacarse que de acuerdo con lo que se ha conservado, en ambos lados el arriate más extremo es más ancho que el situado junto al pórtico central del crucero. Esto hace sospechar que la construcción del actual pórtico central del crucero trajo consigo una modificación de estos arriates cercanos. Seguramente, en la etapa inicial, el andén situado en el eje mayor del patio era más estrecho, permitiendo que los pequeños cruceros fueran simétricos. Al construirse la estructura que hoy subsiste con una mayor anchura, tuvieron que reducirse los arriates más próximos sin que se creyera conveniente reestructurar toda la planta del jardín. Si hacemos estos arriates de igual anchura que los 
de los extremos, nos queda de todos modos un gran andén central en el eje mayor, en el que no creemos que hubiera un pórtico soportando un andén superior, sino que más bien hay que pensar que pudo haber una alberca o ría como se dispuso en el patio de la Casa de la Contratación. En este caso, y por mantener las proporciones, pudo haber también albercas o rías en un andén transversal formando el crucero, pero siempre a nivel del jardín.

El pórtico sur quedó totalmente sustituido por un pórtico gótico en la segunda mitad del siglo XIII, cuando todo el lado meridional del patio se reconstruyó en este estilo (fig. 8). Sin embargo, considerando la ubicación del muro que suponemos cimiento del salón sur islámico, resulta el patio simétrico respecto al eje del actual andén transversal del crucero gótico. Esto nos permite suponer que el eje transversal no se cambió de ubicación en la reforma gótica, sino que simplemente se adelantó la posición del pórtico meridional para poder dar mayor anchura al salón principal, como ya dijimos anteriormente. Considerando la simetría respecto a ese eje transversal, se puede pensar que en el lado sur existió inicialmente un pórtico semejante al del lado norte y que el patio era por tanto perfectamente regular y simétrico.

Nos queda por conocer por dónde se accedía al nivel inferior o del jardín. Está bien documentado que el actual acceso es obra del siglo XvI, realizada en el año 1577 (Marín 1990: 287). Para construirlo hubo que abrir una galería por debajo de los dos salones góticos comunicando este jardín de crucero con el jardín de la Danza y el resto de los jardines del Alcázar que, a partir de ese momento se remodelan y decoran, transformándolos de su primitiva estructura de huerta-jardín islámico en jardín renacentista. Es obvio que el acceso primitivo nunca pudo ser por este punto, pues ya hemos indicado que la muralla de la Dār al-Imāra cerraba por aquí el flanco meridional y es impensable que el interior del patio del palacio más importante del Alcázar tuviera su acceso desde el exterior del mismo. En ninguno de los muros perimetrales de esta zona baja se aprecia abertura alguna ni indicios de ningún hueco tapiado que pudiera relacionarse con un acceso. Sólo en el ángulo suroeste, en el último tramo del pórtico gótico, existe el arranque de una escalera que, tras atravesar el muro medieval cristiano y llegar a topar con el supuesto muro de sustentación del salón islámico, gira hacia el oeste $180^{\circ}$ para continuar en un nuevo tramo, quedando inmediatamente interrumpida por el pavimento y el muro actual del pórtico dieciochesco. No resulta aventurado suponer que esa escalera es, cuando menos, el acceso al jardín inferior del palacio gótico, que quizá respetó el acceso primitivo de época islámica. Esta escalera quedaba situada en el extremo occidental del pórtico sur del patio. Pese a su pequeño tamaño, no plantea difi- 
cultades especiales admitir esta hipótesis, pues el jardín inferior no estuvo concebido como lugar al que accediera mucha gente. Por otro lado, las escaleras situadas en casas o palacios de época islámica nunca han contado con un gran desarrollo formal o espacial. Respecto a otra posible hipótesis de que el acceso pudiera haberse realizado por el espacio que se introduce debajo del salón septentrional, hay que resaltar varios inconvenientes. El primero sería lo insólito de la solución, si bien es cierto que todo en este patio resulta bastante inusitado. Pero además, el punto en que habría que situar la escalera formó parte, sin duda, de lo que fue el Patio del Yeso y sus dependencias, lo que no resulta lógico habida cuenta de la independencia espacial y funcional que siempre caracteriza a las distintas unidades residenciales que se agrupan en cualquier palacio islámico (Bermúdez 1973: 56). Además, resulta impensable alejar el acceso al jardín del propio patio, pues esto supondría una clara disfunción. Otra hipótesis que conviene tener en cuenta sería el pensar que existieron escaleras en los dos frentes de los dos pórticos de los salones, que permitirían bajar al jardín de un modo directo. El nada despreciable desnivel de 4,70 m existente obligaría en este caso a una solución difícil de imaginar, pero con la que puede guardar relación la fortaleza de los pilares en esta zona central y el hecho de que, con la construcción del andén central elevado, desaparecería toda la estructura de las supuestas escaleras.

Pese a los pocos elementos conservados de este primitivo patio, no cabe duda de que nos encontramos ante una de las más originales soluciones nunca planteadas en la arquitectura residencial de al-Andalus. El patio de mayor tamaño de los hasta ahora conocidos en ningún palacio andalusí presentaba su suelo rehundido más de cuatro metros y medio respecto al nivel de sus salones. En este nivel inferior se organizó un jardín, seguramente de crucero, con albercas o rías en sus andenes principales que definían otros jardines de crucero de segundo orden, con una disposición en parte semejante a la que presentaba el gran patio del palacio del Badī' en Marrākuš (Meunier 1957: Pl. IV, Torres Balbás 1958: 187). Todo ello rodeado de pórticos en sus cuatro lados que sostenían las zonas de circulación del nivel superior: simples andenes en los laterales y los pórticos de los salones en los frentes. Podemos llegar a imaginar el centro de este jardín ocupado por una gran fuente o, incluso, por un pabellón semejante al que sabemos se levantaba en el gran jardín de crucero del Alcázar Sagir de Murcia, construcción atribuida a Muhammad Ibn Mardanīš a mediados del siglo XII (Navarro 1998: 105). Los dos salones principales, situados en los testeros más cortos del patio, de proporción larga y estrecha, en nada diferirían de lo habitual en las casas y palacios andalusíes. 
Sin duda, lo más original de este patio es su disposición en dos niveles y la ubicación del jardín en situación rehundida. No se conocen paralelos directos de este ordenamiento en al-Andalus, pero se puede establecer una cierta relación con una forma arquitectónica bastante extendida en oriente, cual es el sirdāb. Este tipo de construcción suele estar constituido por una excavación realizada bajo el nivel del terreno que contiene alguna habitación o espacio subterráneo y con frecuencia algún depósito o lámina de agua. Merece mencionarse el gran sirdāb del Ŷawsaq al-Jāqānī, en Samarra, de planta circular y que disponía de una gran alberca con distintas habitaciones alrededor excavadas en el terreno y con abertura hacia el espacio central (Northedge 1993: 148-149). Su función era, sin duda, proporcionar un lugar fresco en que poder pasar los rigores estivales, función que sin duda hay que atribuir también a este jardín sevillano.

Las dimensiones, forma y originalidad de este palacio permiten suponer que se trataba del más importante de cuantos encerraba el recinto de los alcázares sevillanos en época islámica y ello justificaría que la gran construcción y reforma realizada por Alfonso X, tras la conquista de la ciudad, tuviera por objeto precisamente este conjunto.

\section{LA REFORMA ALFONSÍ}

No existe documentación coetánea útil para nuestro estudio en relación con las reformas y construcciones realizadas por Alfonso X en el Alcázar, y tenemos además que acudir a referencias y descripciones posteriores para conocer muchos de sus detalles, ya que las transformaciones realizadas tanto en el siglo XVI como sobre todo en el XVIII han alterado sobremanera las estructuras de este palacio gótico.

Como en tantos casos ha ocurrido, tras la conquista de Sevilla por los castellanos, pasaron a dominio del rey los antiguos palacios reales islámicos de la ciudad. La estructura de estos palacios, más concebidos como residencias domésticas y para la vida placentera y el disfrute de sus patios y jardines que para una actividad cortesana protocolaria, debió de plantear dificultades a sus nuevos habitantes. A ello se uniría el deseo de dar una imagen del poder nueva y distinta que manifestara la nueva realidad social y política advenida (Cómez 1996: 164). En este primer estadio, previo a la seducción que la cultura andalusí provocaría de forma casi inmediata en los conquistadores, se producen en Sevilla, como en otros lugares de las zonas recién conquistadas, una serie de construcciones de estilo gótico de notable pureza, influenciadas por las 
realizaciones arquitectónicas de ese momento en Castilla y León (Chueca 1965: 357). Sin embargo, la implantación de estas estructuras góticas, posiblemente por la ausencia en los reinos cristianos de modelos palatinos bien establecidos, se hizo de forma mucho más respetuosa con la primitiva estructura islámica de lo que en principio cabría esperar. De hecho, se mantuvo la estructura del patio y la disposición de los dos salones enfrentados en sus dos extremos, característica de las casas y palacios andalusíes (figs. 6, 7). La zona norte, cuyo salón orientado al mediodía debía ser el principal del palacio islámico, no debió ni siquiera alterarse, pues las descripciones del siglo XVI así parecen indicarlo. La gran transformación se produce, pues, en el lado meridional en donde, sin alterar la estructura básica del palacio, se disponen una serie de nuevos salones para dotarlo de mayor capacidad y prestancia.

La transformación realizada podemos sintetizarla en los siguientes puntos:

- El salón meridional se amplía hacia el patio dándole una mayor anchura y, consecuentemente, el pórtico que le antecede se desplaza igualmente hacia el norte.

- Este salón principal, que ocupaba lo que hoy se conoce como Salón de los Tapices de Carlos V y en otros tiempos como sala de las Bóvedas o de las Fiestas, se rodea de otros tres salones, uno paralelo al antes mencionado, entre éste y los jardines, y otros dos perpendiculares al anterior que flanquean el conjunto. Estas tres crujías perimetrales son de anchura similar, algo menor que la del salón central.

- La construcción de estas estructuras, realizadas en estilo gótico, trajo consigo la demolición del salón meridional del palacio islámico, de su pórtico y del pórtico inferior del jardín.

- También debió de ser demolida la muralla meridional de la Dār al-Imāra y la torre que con toda seguridad debió existir en el ángulo suroeste del recinto. Esta demolición era obligada para poder disponer de suficiente espacio para las nuevas salas que se organizaron alrededor del salón central. No obstante, un fragmento de la muralla occidental ha debido quedar conservada como muro de separación entre el salón principal y el pórtico por un lado y la sala que flanquea el palacio por el oeste del otro. Tal aseveración se basa en que dicho muro es notablemente más grueso que los otros del palacio gótico y en que sigue con la alineación y el grosor del lienzo de muralla 
cuyo paramento aún es visible en el tramo comprendido entre el extremo norte del palacio gótico y la línea de fachada del palacio mudéjar de don Pedro. Precisamente debió de ser la alineación oblicua de esa muralla la que motivó el giro que presenta esa crujía lateral, que no es ortogonal a los salones principales.

- Como la muralla derribada y la que quedó incluida dentro de las nuevas construcciones seguían teniendo una función defensiva importante, toda la zona sur y oeste del nuevo edificio se organizó con carácter militar, disponiendo pequeños contrafuertes que hacen función de torres y con almenado en todo el conjunto (fig. 11). Aunque el lado oriental quedaba dentro del recinto, se le dio el mismo carácter para mantener la simetría del edificio. $\mathrm{El}$ aspecto de esta organización externa se ha querido comparar con precedentes islámicos como son la mezquita de Córdoba y la misma mezquita aljama almohade de Sevilla. Ambos edificios, al igual que otros muchos semejantes, presentan contrafuertes de regular tamaño que alcanzan la misma altura que los muros y se rematan con almenas como éstos. Es posible que tal influencia se haya dado, pero no debemos de olvidar que en nuestro caso, y a diferencia de lo que ocurre en los ejemplos islámicos mencionados, los contrafuertes obedecen a la lógica estructural gótica que establece siempre los elementos resistentes en donde lo requieren las líneas de fuerza, aunque es indudable que el aspecto exterior de este edificio más tiene que ver con la arquitectura de su entorno que con los edificios góticos que en esos momentos se levantaban en Castilla.

El resultado de esta disposición es una planta de palacio musulmán con uno de los lados hipertrofiado al envolver el salón de ese lado con tres crujías perimetrales. Es difícil encontrar paralelos a la original disposición así resultante. Nos encontramos ante un palacio organizado en tres crujías paralelas flanqueadas por otras dos perpendiculares. Pese al indudable aspecto gótico de esta construcción y a los pretendidos paralelismos con construcciones palatinas de Francia y otras zonas europeas (Cómez 1974: 139; Lambert 1956: 168; Dubourg-Noves 1971: 167), los edificios con plantas más semejantes los encontramos en la arquitectura islámica. En Medina Azahara hay al menos dos construcciones con organización de triple crujía. Una es la llamada Dār al-Mulk, que se supone la residencia privada del califa 'Abd al-Raḥmān III (Almagro 1996: 218-219). El núcleo principal de esta residencia está formado por un salón principal, de proporción alargada precedido por una sala-pórtico como suele ser habitual en los salones de esta 
ciudad áulica. Salón y pórtico tiene en sus dos extremos alcobas de proporción casi cuadrada. Detrás del salón hay otra crujía más estrecha ocupada por una sala con alhanías o alcobas laterales. La sala pórtico abre hacia una terraza sobreelevada respecto al terreno que hay delante y que poseía unas soberbias vistas del paisaje circundante y quizá de los jardines que pudo haber a sus pies. En la composición, las alcobas laterales, aunque están incomunicadas entre sí, hacen las veces de las crujías perpendiculares del palacio gótico del alcázar sevillano. Esta misma disposición fue la que muy posiblemente tuvo la residencia califal de alRummāniyya (Ocaña 1984), excavada y considerada por R. Velázquez Bosco como al-'Āmiriyya (Velázquez 1912) y hoy desgraciadamente destruida.

Una organización también con triple crujía aparece en el lado occidental del llamado Patio de los Pilares, en la misma ciudad palatina de los califas omeyas. En este caso tenemos un pórtico de pilares cuadrados que precede a dos salones alargados, puestos en paralelo y comunicados entre sí por tres puertas, si bien las crujías perpendiculares no están aquí presentes de una forma tan rotunda. En el lado norte hay una escalera y una alcoba, mientras el lado sur se encuentra muy destruido y su interpretación presenta dificultades. De todos modos, es posible que existieran alcobas como hay en casi todos los salones de este edificio. Resulta difícil determinar si existió un hilo conductor entre los modelos de Medina Azahara y el palacio alfonsí, pero no es totalmente descartable sobre todo si admitimos las posibles influencias que los palacios califales tuvieron en alguna otra realización sevillana (Manzano 1995a: 344).

Analicemos con cierto detenimiento este palacio gótico, pues aparte de su indudable calidad arquitectónica, algunos detalles nos siguen dando pistas sobre la construcción que le precedió.

Un primer tema de análisis es el de la iluminación que poseían estos salones. En el siglo XVI se hace mención de la oscuridad de estas salas, razón por lo que en ese momento se abrieron grandes ventanas. En las fachadas sur, este y oeste, los huecos de iluminación debieron ser altos para garantizar el carácter defensivo de esta parte del edificio. En la zona superior de la fachada exterior meridional se pueden observar los remates de dos ventanas. Por su situación y aspecto, cabe suponer que se trata de huecos de arco apuntado que debían estar situados a notable altura sobre el suelo, con su clave cercana a la bóveda del salón (figs. 9, 11). No sabemos cuántas ventanas hubo, aunque quizá podamos pensar que las ventanas actuales, que son tres, coinciden en situación con las primitivas, si bien éstas se abrieron a ras de suelo y con mayor tamaño. De hecho las dos extremas coinciden en situación con los restos de las dos góticas. Por tanto, puede pensarse que habría otra en el centro coincidien- 
do con la hoy existente. No creemos además que se tapiaran ventanas originales sin abrirse otras debajo. Para las salas laterales no hay más indicio respecto a la forma en que se iluminaban que la existencia de unos óculos en la fachada oriental que quizá sean originales y la insinuación de una ventana apuntada en el salón occidental, hoy capilla, que quedaría tapiada al construirse el palacio de don Pedro. Los huecos de ventanas existentes al nivel de suelo en estas dependencias corresponden $\sin$ duda a reformas posteriores.

El salón principal creemos que contaría con huecos abiertos hacia el patio, que probablemente estarían cercanos al suelo, aunque serían de pequeño tamaño. Posiblemente estos huecos se agrandarían para dar lugar a los actuales que corresponden a los abiertos en el siglo XVI cuando se les dotan de las rejas que hoy tienen (Marín 1990: 279-281).

La nueva construcción se remataba con una gran terraza de 53 por $23 \mathrm{~m}$ que podía hacer de plaza de armas, a la que se accedía por cuatro escaleras de caracol alojadas en las cuatro torres-contrafuerte de los ángulos y que dieron nombre al palacio durante la época medieval, ya que se le cita en varias ocasiones como el «cuarto del caracol» (Cómez 1996: 31-32).

Para dar sustentación a las nuevas estructuras se construyó en el nivel inferior un grueso muro para asiento de la pared frontal del salón y un pórtico con grandes pilares y arcos apuntados de ladrillo (fig. 8). Los pilares se alternan con planta cuadrada y rectangular, salvo en los extremos en que los últimos son rectangulares para poder recibir los arcos extremos de las galerías laterales islámicas. El pórtico se cubre con bóvedas de ojivas construidas de ladrillo como los pilares y los muros (lám. 9). Aunque esta estructura se transformó y reforzó, tras el terremoto de Lisboa de 1755, con el macizado parcial de algunos arcos y con la construcción de un gran muro de refuerzo exterior que recorre toda la fachada (lám. 10), la disposición del pórtico inferior gótico es perfectamente visible. Además, con anterioridad, cuando en 1577 se da acceso al jardín inferior del patio desde el jardín de la Danza, a través de un pasaje abovedado que atraviesa por el eje el basamento del palacio gótico (fig. 2), se produjo una modificación de la parte central del pórtico al eliminarse el pilar dispuesto en el eje y construirse una nueva bóveda ojival centrada que sustituyó a las dos medias bóvedas originales. Testimonio de esta transformación lo constituyen las dos medias bóvedas conservadas a ambos lados, así como los arranques de los primitivos arcos del pórtico, visibles por su cara exterior.

Merece resaltarse la disposición de este pórtico con pilar en su eje en lugar de vano, que puede ser un reflejo de la también anómala organización que hemos supuesto en los pórticos laterales de época almohade en que se produce 
una solución semejante. Como en el caso del pórtico islámico septentrional, pensamos que aquí se producía una relación entre huecos inferiores y superiores semejante, que estaría marcada por la presencia de pilares alternos cuadrados y rectangulares en el nivel inferior. Posiblemente estos últimos, de mayor sección, servían de sustentación a los del pórtico superior que tendría la mitad de arcos que el del nivel bajo, es decir, sólo cinco. Esta hipótesis choca con la documentación del siglo XvI que nos habla de los pagos por pintar ocho arcos en la galería meridional del patio (Marín 1990: 283). Sin embargo, tales datos resultan difícilmente acomodables a ninguna hipótesis plausible, empezando por el hecho de que se cite un número par de arcos, lo que implicaría una solución con pilar en el eje, que resulta inadmisible en el nivel superior, rompiendo el acceso principal a los salones. Quizá una solución a este dilema sería suponer que puesto que dichos pagos fueron haciéndose de forma sucesiva, pudo haberse omitido o anotado dos veces algún pago en las cuentas.

La otra gran transformación que sufrió el patio en época alfonsí consistió en establecer una amplia comunicación entre el salón septentrional y los nuevos salones construidos en el lado sur al nivel de la planta baja. Ya hemos indicado que hasta entonces la única comunicación era a través de los andenes altos que corrían por los lados del patio. Estos andenes eran en cualquier caso de poca anchura, apenas 1,60 m, y carecían de las condiciones para permitir un acceso protocolario desde la entrada al patio, que hemos supuesto situada en el lado norte, y los salones meridionales. Con el fin de establecer una amplia avenida de acceso a este lado sur, se construyó un andén elevado sostenido por una estructura abovedada dentro de la cual se mantuvo una alberca alargada (figs. 9 , 10, láms. 5-6). Pequeños corredores se dispusieron a los lados de ésta atravesando los pilares y formando dos pasadizos paralelos (lám. 7). Para dar mayor rotundidad al diseño se organizaron otros andenes transversales, formando un crucero en el nivel superior que reprodujo, sin duda, el diseño de un crucero inferior que ya existía en el jardín islámico (lám. 8).

Ya hemos indicado cómo estos andenes transversales y sus pilares alteraron la forma y disposición de los pórticos laterales almohades, eliminando el pilar central de los mismos. Su diacronismo viene además atestiguado por la falta de correlación que existe entre los pilares y vanos de los pórticos que sustentan el crucero central y los de los pórticos perimetrales. Para contrarrestar los empujes de las bóvedas de la galería central del crucero, se dispusieron contrafuertes de planta prácticamente cuadrada que sobresalían hacia el jardín (lám. 4). En los andenes transversales del crucero no parece que existieran elementos de contrarresto ya que la menor anchura del mismo y la dirección en que se dis- 
pusieron las bóvedas no lo hacía necesario. Toda esta organización, que en total resultaría más ancha que el andén antiguo, obligaría a reducir el tamaño de los arriates inmediatos a dicho andén central, produciéndose la asimetría que hoy se observa.

El patio así configurado se conservó en sus líneas básicas hasta las grandes modificaciones realizadas tras el terremoto de Lisboa. A pesar de las importantes reformas efectuadas en el siglo XVI, éstas afectaron más a aspectos ornamentales que a la disposición espacial y estructural. Por ello, el texto que escribió Rodrigo Caro sobre este patio y su jardín a comienzos del siglo XVII sigue siendo una descripción bastante precisa y fidedigna de este memorable palacio, que era ya entonces el fruto de la acomodación del concepto original de un jardín en un patio rehundido a necesidades y situaciones culturales diversas, pero que mantuvieron los indiscutibles valores originales de esta sin par creación arquitectónica. Por su interés, creemos conveniente reproducirla en su integridad:

«De aqui se entra a otro patio, que llaman Cruzero, porque su forma es de Cruz; y aunque en él se entra llanamente, tiene debaxo un jardín subterraneo de Naranjos, dividido en quatro quarteles; y es tan hondo, respecto deste patio, que apenas salen a emparejar los pimpollos de los árboles con el. Formase este Cruzero sobre fortissimos arcos de ladrillo, y cantería, con estribos calados por una, y otra parte; de modo, que contienen dentro de si un gran estanque de agua, que corre por lo baxo todo lo que el Cruzero por lo alto, y por los lados deste jardín ay también corredores, que sustentan los andenes, y corredores del patio de arriba: el qual está todo hermosísimamente labrado, con pretiles por una, y otra vanda, cubiertos de azulejos, començando en una pila de mármol donde hay un saltadero de agua, cercado en buena proporción de lossas y mármol blanco: de modo que este patio, assi por el mucho cielo que goza, como por su extraordinaria hechura, y las vistas al jardín subterráneo, es muy alegre, y grandioso, y lo que por lo baxo cubre, es para de verano la cosa más sombría, y fresca que se puede imaginar. Esto juzgo aver quedado del antiguo Alcázar de los Moros, junto con el quarto que llaman del Maestre, que esta luego como se entra, a mano derecha: y llamase assi, poque alli mato el Rey don Pedro a su hermano don Fadrique Maestre de Santiago, y muestran los vestigios de su sangre, aun toda via. Frontero de este antiguo quarto del Maestre esta al fin del Cruzero un corredor labrado sobre arcos, y pilastras de fortissima canteria, al qual se entra por una puerta de verjas de hierro curiosamente labrada, y dorada. Deste corredor se entra por una gran portada a un salon de bobeda de ciento treinta pies de largo, y treinta de ancho; y despues del, mediando sola una muralla, esta labrado otro salon de la misma largura, aunque es algo menos ancho, y a la parte de a fuera 

de hierro, y por ella entra luz bastante a ambos salones, sobre los quales no hay otro edificio, sino una azotea descubierta sobre la bobeda que los cubre» (Caro 1634: 56).

Las modificaciones introducidas en el siglo XVI afectaron, como ya hemos dicho, a aspectos ornamentales aparte de la apertura de grandes ventanales. Consistieron básicamente en forrar las zonas bajas de los paramentos con bellos zócalos de azulejos de Triana. Una duda que se plantea es si como afirma A. Marín (1990: 276) se eliminaron con tal fin unas supuestas columnas o pilastras que recibían las nervaduras de las bóvedas de ojivas. Si tales pilastras existieron, no cabe duda que eran un impedimento que dificultaba la colocación de los zócalos. Esto justificaría la colocación de las ménsulas renacentistas diseñadas por Asensio de Maeda (Marín 1990: 277), aunque también cabe la posibilidad de que dichas ménsulas sustituyeran a otras góticas y que nunca hubiera habido columnas ni pilastras. Por lo demás no entraremos en más detalles sobre estas reformas ya que han sido descritas ampliamente por A. Marín (1990: 271-292).

Todo el lado norte del patio sufrió una radical reforma en fecha no precisada, pero en cualquier caso con posterioridad a 1578, cuando en diversos documentos se propone su reparación y parcial refacción. En el plano atribuido a Vermondo Resta (Marín 1990: 356) sigue apareciendo, como ya indicamos, el pórtico, del que los documentos dicen que está sustentado por pilares de ladrillo, y un resto de la primitiva sala del Maestre. En el plano de Sebastián van der Borcht de 1759 ya no queda indicio ni del pórtico ni de la sala, estando todo subdividido en pequeñas habitaciones, al igual que el cercano Cuarto del Yeso.

\section{LA REFORMA DEL SIGLO XVIII}

El Patio del Crucero toma su fisonomía actual tras las obras efectuadas después del terremoto de Lisboa de 1755 por el ingeniero Sebastián van der Borcht. El terremoto debió afectar gravemente al palacio alfonsí. Puesto que la estructura del palacio gótico resultaba más endeble por el lado del patio que por la fachada meridional dotada de poderosos contrafuertes, no resulta difícil de imaginar que el terremoto afectó de modo especial al pórtico y al salón inmediato ya que el empuje de sus bóvedas se encontraría más desequilibrado por el lado norte. La ruina afectó, pues, al pórtico y al gran salón central que tuvieron 
que ser reconstruidos. No sabemos si el muro que separa a ambos espacios fue rehecho desde el nivel del suelo, pero los pilares del pórtico y las bóvedas de los dos ámbitos fueron totalmente reconstruidas.

Con el fin de dar mayor estabilidad a la estructura, los pilares del pórtico se diseñaron más robustos que los anteriores y sobre todo, con mayor sección en la dirección de los empujes de las bóvedas merced a la disposición de columnas pareadas frontales (fig. 1). Con tal fin tuvieron que reforzarse los cimientos, macizándose partes de los arcos del pórtico gótico inferior y construyendo unos gruesos arcos en parte macizados con un muro de $1,17 \mathrm{~m}$ de espesor por delante de aquél (fig. 2, lám. 10). La galería del pórtico inferior se subdividió en pequeñas habitaciones mediante muros que reforzaban los arcos formeros con pequeñas puertas a eje, que le confieren una secuencia espacial absolutamente distinta de la original.

Todo el palacio gótico cambió radicalmente de aspecto. Se dispuso una fachada de estilo barroco, a base de un pórtico con cinco grandes arcos, soportados en gruesos pilares con dobles columnas frontales. Sobre este pórtico se integró una entreplanta con balcones, rematándose todo con la correspondiente cornisa y una balaustrada con jarrones ornamentales. Tras el pórtico, se reconstruyó el salón con bóvedas baídas que han permanecido inacabadas, a falta de la decoración, hasta las recientes obras de reacondicionamiento del salón efectuadas por R. Manzano. A la bóveda central se la dotó de una linterna que sobresale en la terraza. Ésta perdió su primitiva unidad, ya que las nuevas bóvedas del salón central y la construcción de la planta alta sobre el pórtico obligaron a sobreelevar la terraza en toda la parte frontal del edificio produciéndose un escalón de $1,60 \mathrm{~m}$ con respecto al nivel de las terrazas góticas.

Sin embargo, la más drástica transformación del patio vino de la decisión de enterrar todo el jardín bajo y subir el nivel de su suelo a ras de los salones. Con este objeto, se tapiaron los arcos perimetrales de cada cuartel del crucero y se rellenaron de tierra éstos, dejando los corredores que rodeaban el jardín como auténticas cámaras bufas que aislaban los muros de la humedad de los jardines, y las galerías del crucero como pasos de servicio. Prácticamente, el primitivo jardín quedó enterrado y olvidado, salvo por el testimonio que supone la descripción de Rodrigo Caro. Parece ser que tras esta transformación el patio quedó todo él pavimentado de ladrillo hasta mediados del siglo pasado en que se ajardinó de nuevo (Fernández García, R. 1995: 91). No sólo la fachada del palacio gótico sufrió una radical trasformación. Todas las fachadas de las demás crujías fueron remodeladas dotándolas de recercados de huecos, cornisas y cubiertas homogéneas, incluyendo el único resto de 
muro islámico del extremo sur del lado occidental. Además, el patio se redujo notablemente de tamaño al construirse en su tercio norte el corredor de comunicación entre el Apeadero, que se alarga con su actual último tramo, y el patio de la Montería. Para sustentar este corredor, se construyeron sendos muros paralelos en el nivel inferior, previamente al enterramiento de los arriates. Al cuerpo formado por dicho corredor se le dotó de una fachada con una hermosa portada barroca hacia la zona del patio, quedando el lado opuesto dando a un patio de luces que equivalía en su mayor parte al primitivo pórtico septentrional del palacio islámico, del que no quedó ningún resto ni estructura aparente.

Toda esta zona permaneció como área de servicio formada por pequeñas habitaciones hasta las obras realizadas por R. Manzano, quien recuperó en lo posible parte de la disposición medieval. Para ello, además de dejar visible y ordenar lo conservado del muro frontal del Salón del Maestre, aunque este muro debe ser ya de factura del siglo XVII, liberó de tierras la zona inferior del corredor de paso entre el Apeadero y la Montería, así como la pequeña zona correspondiente a los arriates antiguos que queda entre dicho corredor y el frente norte. De este modo quedaron visibles, por primera vez en mucho tiempo, parte de los frentes exteriores de los pórticos bajos del jardín medieval, lo que ha permitido plantear buena parte de lo aquí expuesto.

El estado actual de este patio no permite apenas discernir al visitante su larga y compleja evolución. Tampoco creemos que pueda avanzarse mucho más en la recuperación de las estructuras medievales, pues tendría que hacerse a costa de transformar radicalmente el actual patio barroco, cosa que debe desecharse absolutamente. Sin embargo, creemos que hoy las nuevas tecnologías nos permiten resolver, a través de la realidad virtual, algunos de estos dilemas y esperamos que en un próximo futuro podamos aportar alguna solución al respecto.

\section{BiBLIOGRAFÍA}

Almagro, A. 1996, «Jardín con plantas (y alzados) de papel», en AA.VV., Arquitectura en al-Andalus, Documentos para el siglo XXI, Barcelona.

—. 1997, Orihuela, A. (ed.), La casa nazarí de Zafra, Granada.

—. 1998, «La imagen de la Aljafería a través del tiempo: evolución morfológica», $L a$ Aljafería II, Zaragoza, 407-421.

Chueca, F. 1965, Historia de la Arquitectura Española, Edad Antigua, Edad Media, Madrid. 
Bermúdez Pareja, J. 1973, «Identificación del Palacio de Comares y del Palacio de los Leones en la Alhambra de Granada», Actas XXIII Congreso Internacional de Historia del Arte, III, Granada, 55-57.

BERMúDEZ LóPEZ, J. 1992, «Una introducción a la estructura urbana de la Alhambra», Al-Andalus. Las Artes Islámicas en España, 153-161, Madrid.

CARo, R. 1634, Antigüedades y Principado de la Ilustrísima Ciudad de Sevilla y Chorographia de su Convento Iuridico, o Antigua Chancillería, Sevilla.

CómEZ, R. 1974, Arquitectura alfonsí, Sevilla.

-. 1996a. «El Alcázar de Sevilla en dos ejemplos de dominación cultural: Alfonso X el Sabio y Pedro I el Cruel», Spanien und der Orient im frühen und hohen Mittelalter, Madrider Beiträge 24, Mainz.

-. 1996b, El Alcázar del rey D. Pedro, Sevilla.

DUBOURG-NovES, P. 1971, «Le style gothique français et les Alcazars chrétiens de Séville et de Cordoue (XIII siècle)», Actes du 94e Congrès National des Societés Savantes, Pau 1969, Paris, 165-185.

FERNÁNDEZ GARCÍA, R. 1995, Historia del Jardín Sevillano: Recopilación y edición crítica de fuentes, Tesis doctoral inédita defendida en el Departamento de Expresión Gráfica Arquitectónica. Universidad de Sevilla.

GESTOSO, J. 1889, Sevilla monumental y artística, Sevilla.

JIMÉNEZ, A. 1981, «Análisis formal y desarrollo histórico de la Sevilla medieval», en AA.VV., La arquitectura de nuestra ciudad, Sevilla, 13-21.

LAMBERT, E. 1956, «L'art Gothique à Séville après la Reconquête», Études Medievales, v. III, Toulouse, 163-171.

MEUNIER, J. 1957, «Le grand Riad et les batiments saadiens du Badī‘ à Marrakech selon le plan publié par Windus», Hespéris, XLIV, 129-134.

MANZANo, R. 1983, Poetas y vida literaria en los Reales Alcázares de Sevilla, Sevilla.

—. 1991, «Patios con jardín en la Sevilla islámica», Temas de Estética y Arte V, Sevilla. 13-48.

-. 1994, La qubba, aula regia en la España musulmana, Madrid.

—. 1995a, «Casas y palacios en la Sevilla almohade»", en Navarro, J. (ed.), Casas y palacios de al-Andalus, siglos XII y XIII, Barcelona, 315-352.

—. 1995b, «El Alcázar de Sevilla: Los palacios almohades», en Valor, M. (coor.), El último siglo de la Sevilla islámica, Sevilla, 101-124.

MARín, A. 1990, El Alcázar de Sevilla bajo los Austrias, Sevilla.

NAVARro, J. 1998, «La Dar al-Sugra de Murcia. Un palacio andalusí del siglo XII», Gayraud, R. P. (ed.), Colloque international d'archéologie islamique, IFAO, Le Caire 3-7 février 1993, Textes et Études Islamiques 36.

NORTHEDGE, A. 1993, «An interpretation of the palace of the caliph at Samarra (Dar alKhalifa or Jawsaq al-Khaqani)», Ars Orientalis, 23. 
OCAÑA, M. 1984, «Las ruinas de Alamiría, un yacimiento arqueológico erróneamente denominado», Al-Qantara, 5, 365-381.

Torres BalbÁs, L. 1958, «Patios de Crucero», Al-Andalus, 23, 171-192.

Velázquez Bosco, R. 1912, Medina Azzahra y Alamiriya, Madrid.

\title{
RESUMEN
}

El presente artículo es una consecuencia de los trabajos de levantamiento planimétrico realizados en los Reales Alcázares de Sevilla. En él se analiza una de las varias unidades residenciales que integraron este conjunto áulico en época medieval, cuya construcción inicial se remonta al período islámico aunque ha sufrido varias y profundas trasformaciones. Del análisis de las distintas estructuras, especialmente a través de la planimetría y la documentación, se deduce la especial originalidad de esta construcción para la que se proponen hipótesis de su forma original en los distintos períodos.

\begin{abstract}
This paper presents some of the conclusions drawn from the surveying of the Reales Alcázares in Seville. It analyzes one of the residential units integrated into the palace which was initially constructed in the Islamic period. Although this unit has suffered many transformations, its original structure can be deduced through plans and documents. Some hypotheses regarding its structure in different periods are proposed here.
\end{abstract}




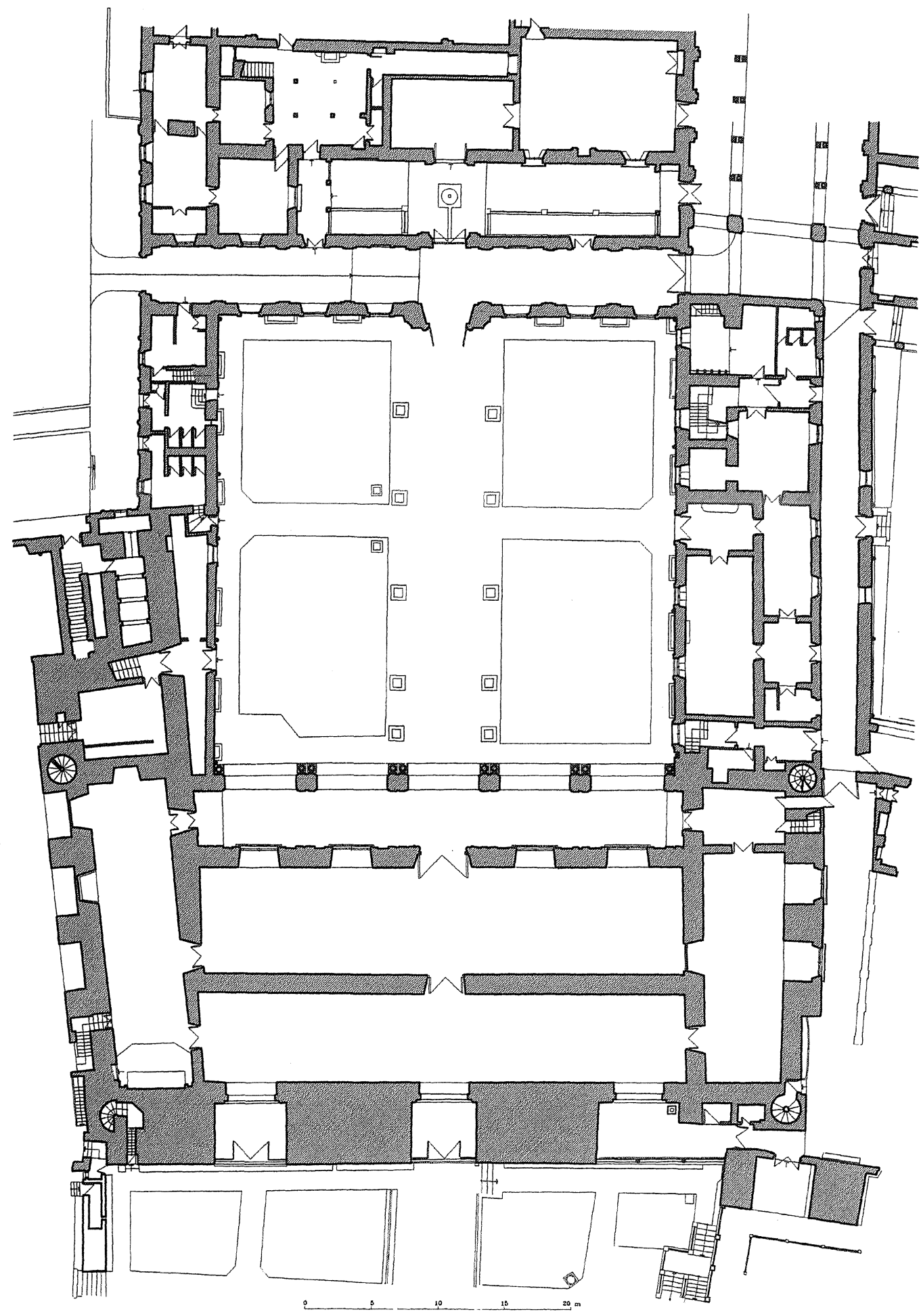

Figura 1. Planta actual del Patio del Crucero. 


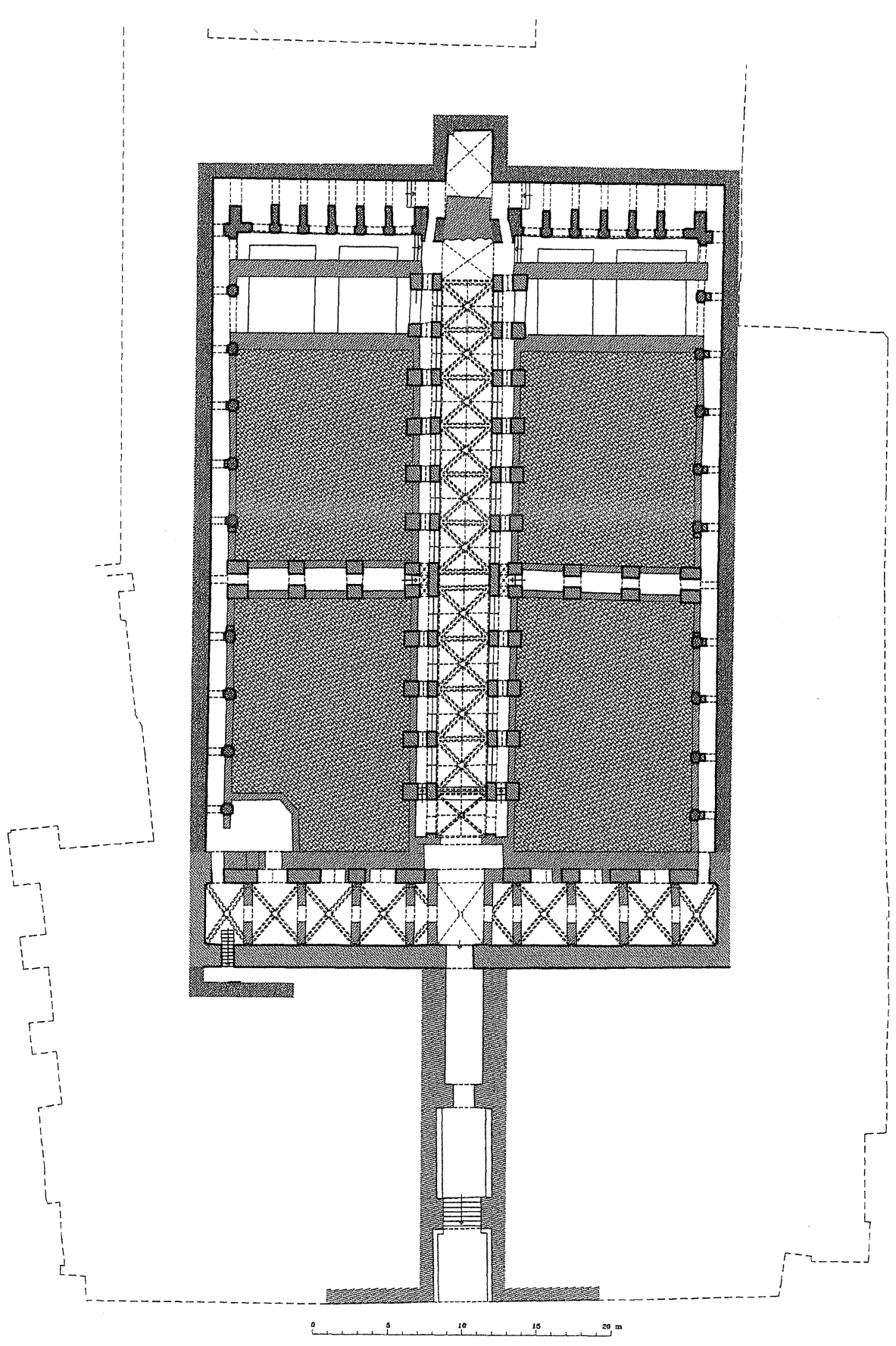

Figura 2. Planta actual del nivel inferior del Patio del Crucero, también llamado Baños de Doña María de Padilla. 


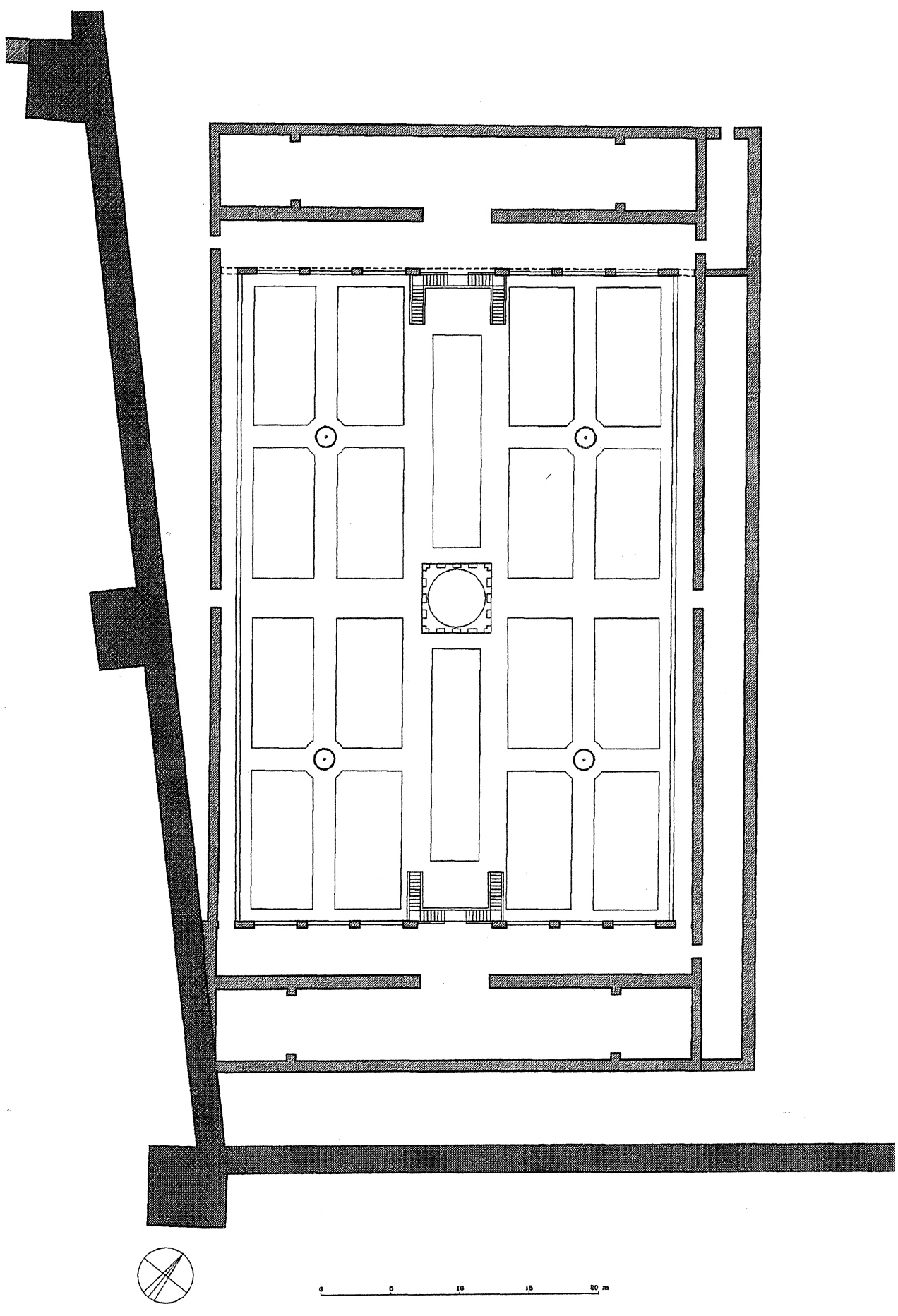

Figura 3. Planta de hipótesis del palacio islámico del Patio del Crucero. 


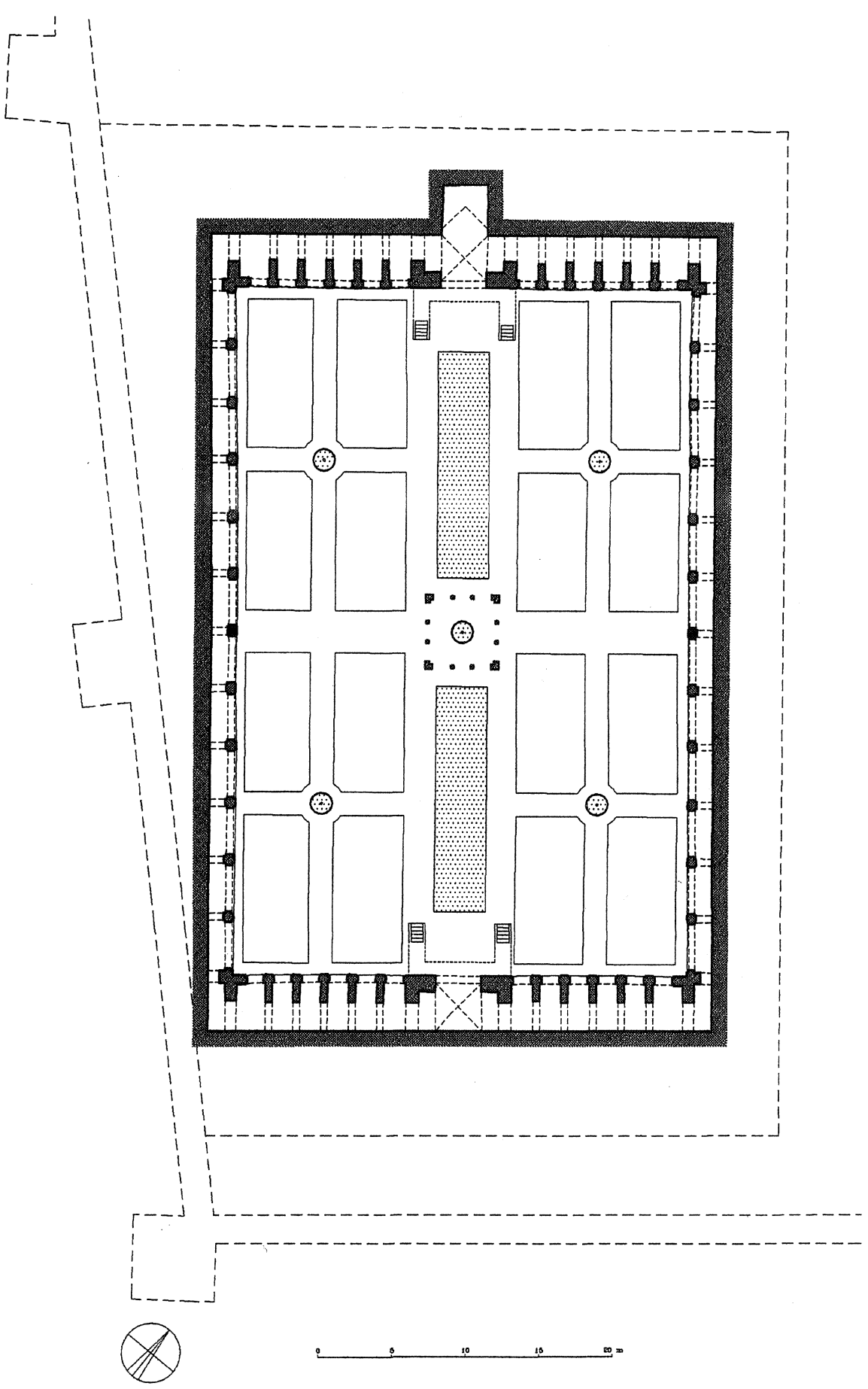

Figura 4. Planta de hipótesis del nivel inferior o del jardín del Patio del Crucero en época islámica. 

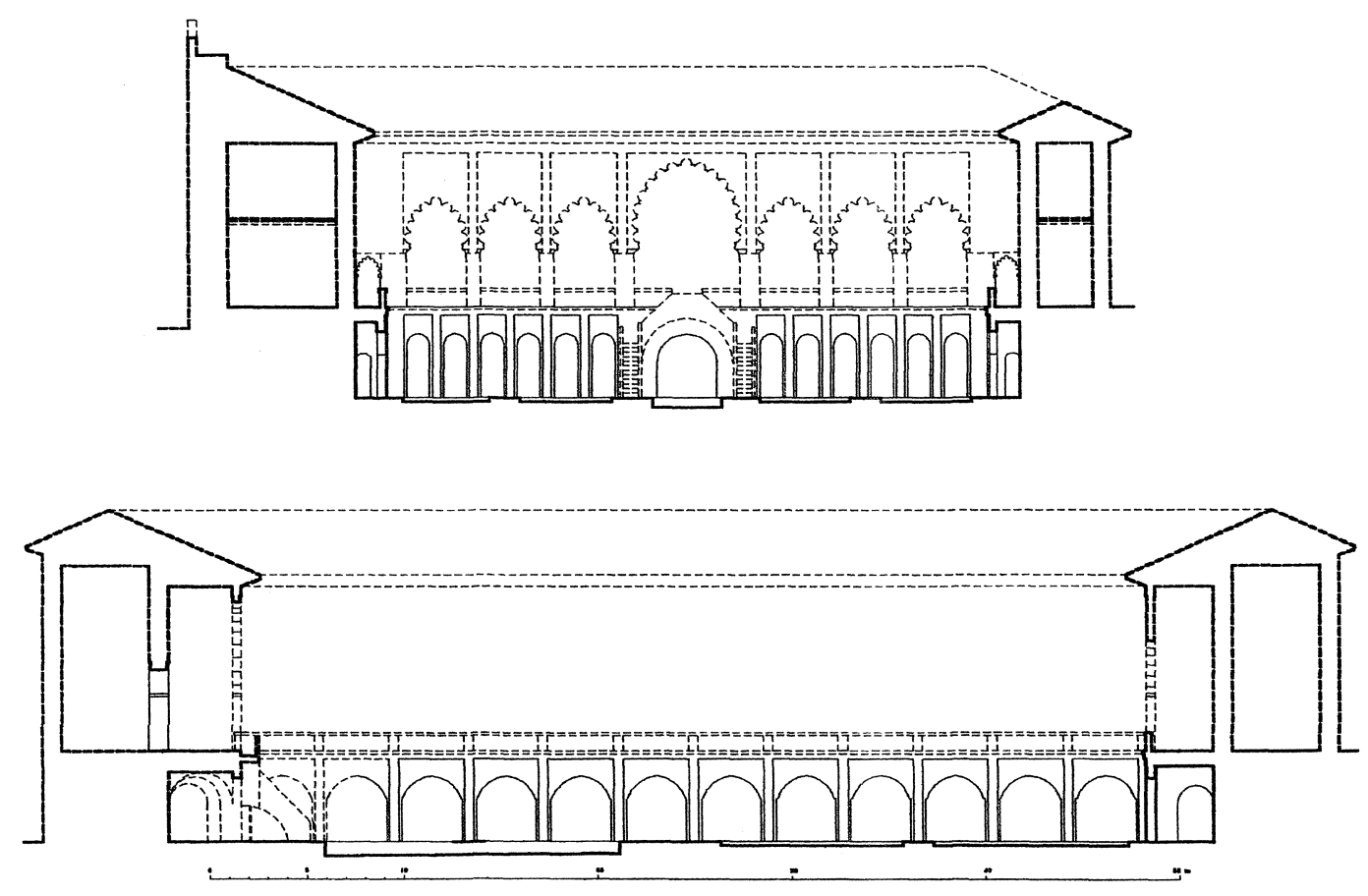

?

Figura 5. Secciones de hipótesis del Patio del Crucero en época islámica. 


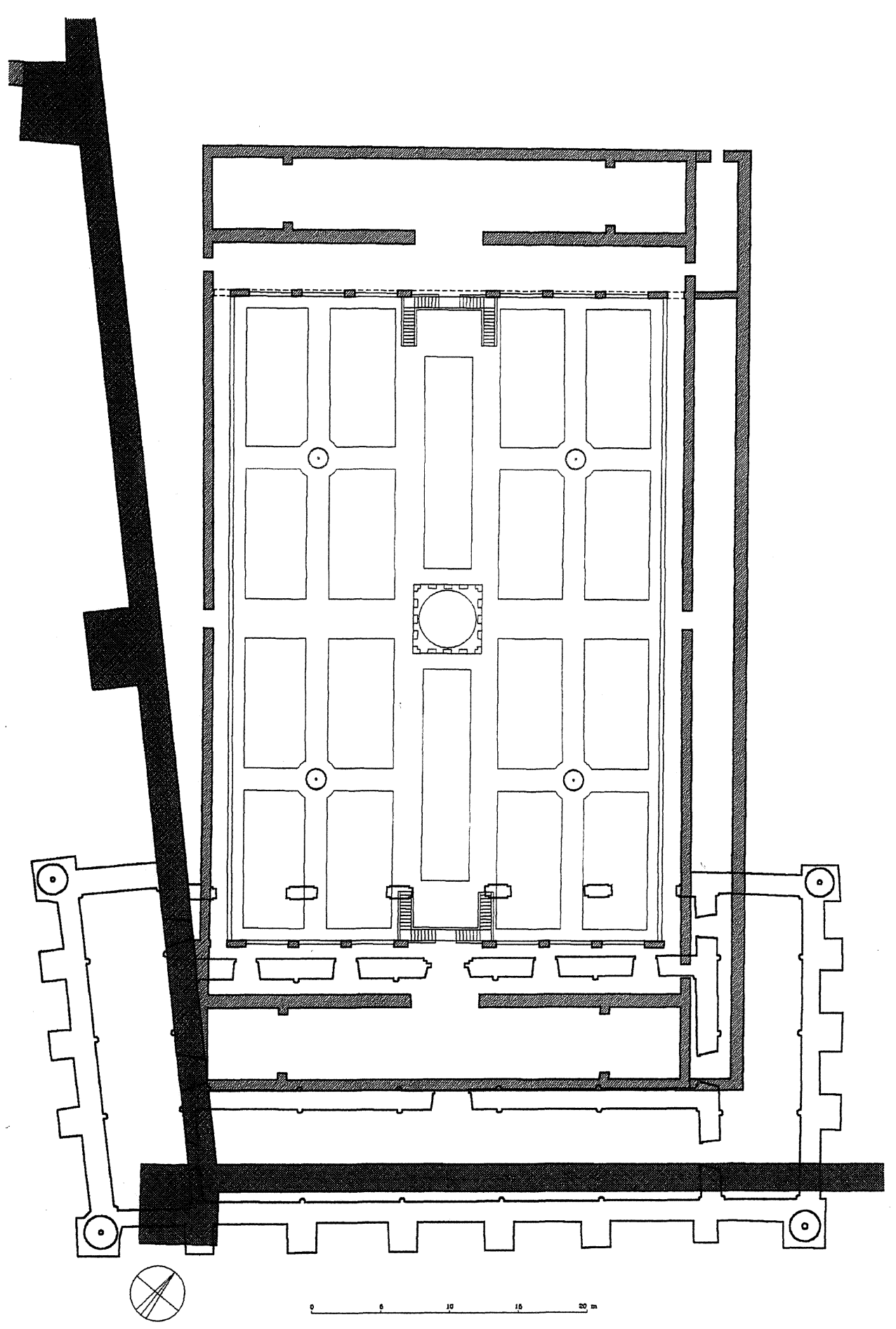

Figura 6. Planta superpuesta del palacio islámico y de las estructuras posteriores. 


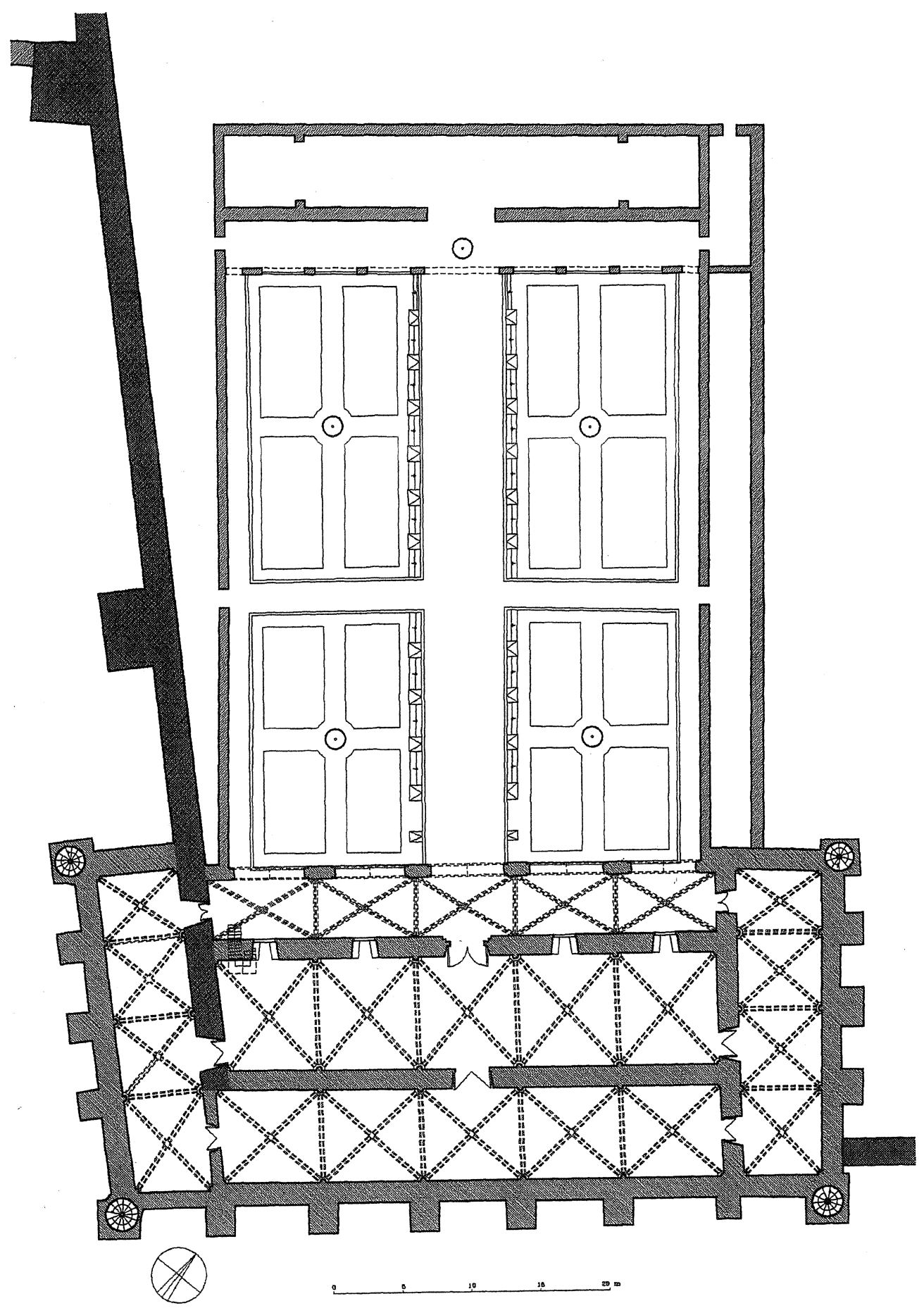

Figura 7. Planta de hipótesis del Patio del Crucero en época alfonsí. 


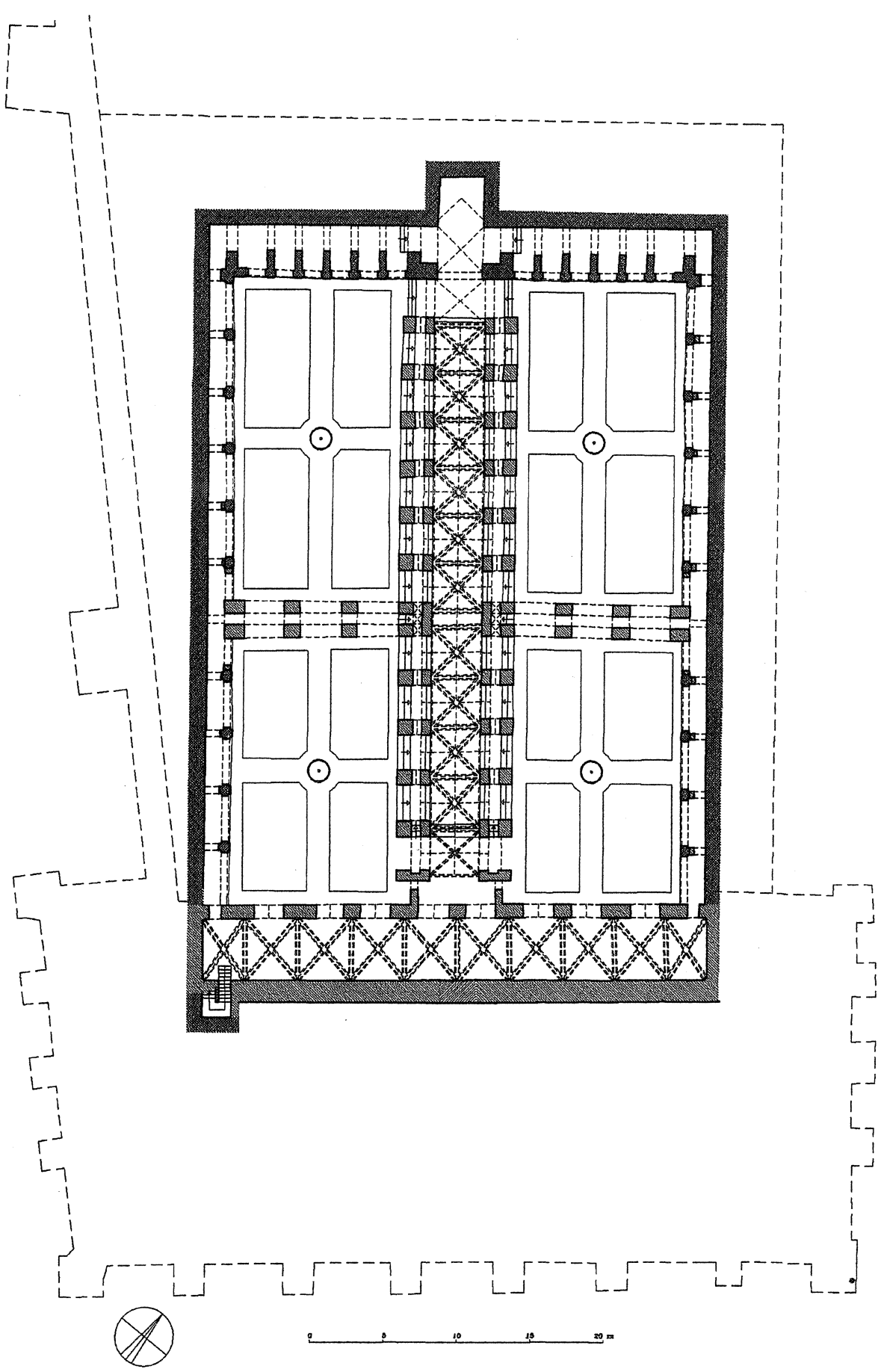

Figura 8. Planta de hipótesis del nivel del jardín del Patio del Crucero en época alfonsí. 

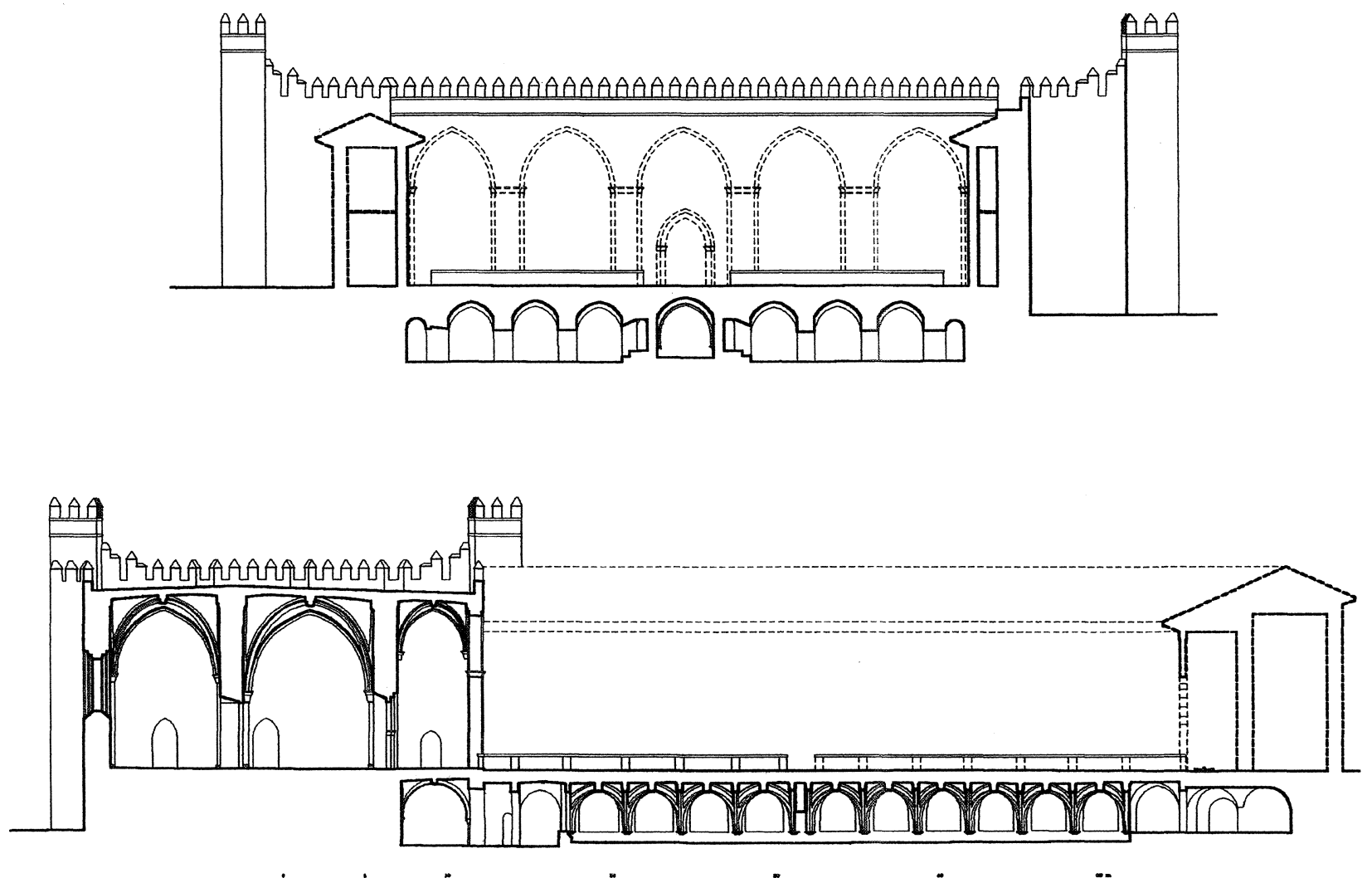

p
3
3
0
0
0

Figura 9. Secciones de hipótesis del Patio del Crucero en época alfonsí, por los ejes. 

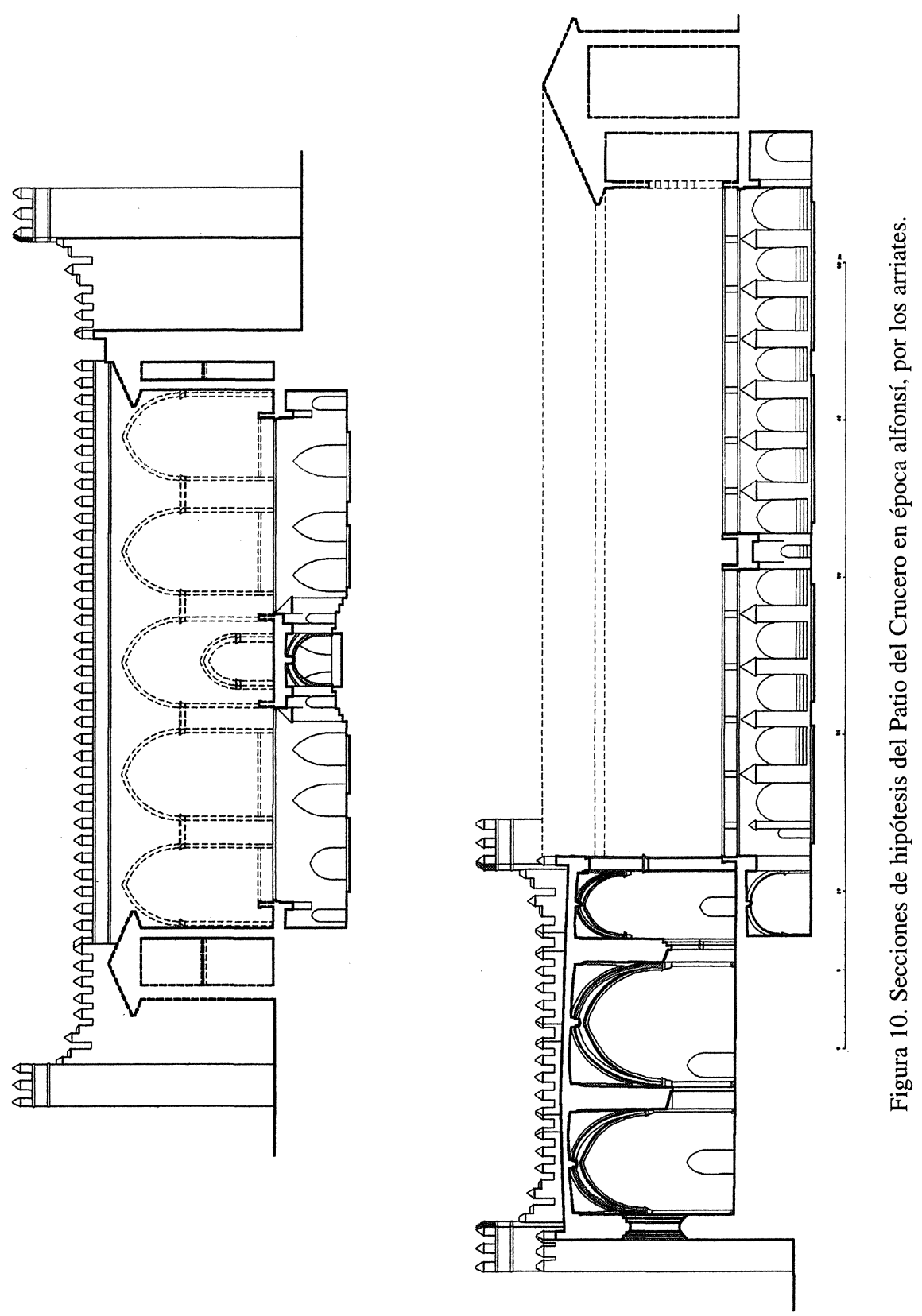


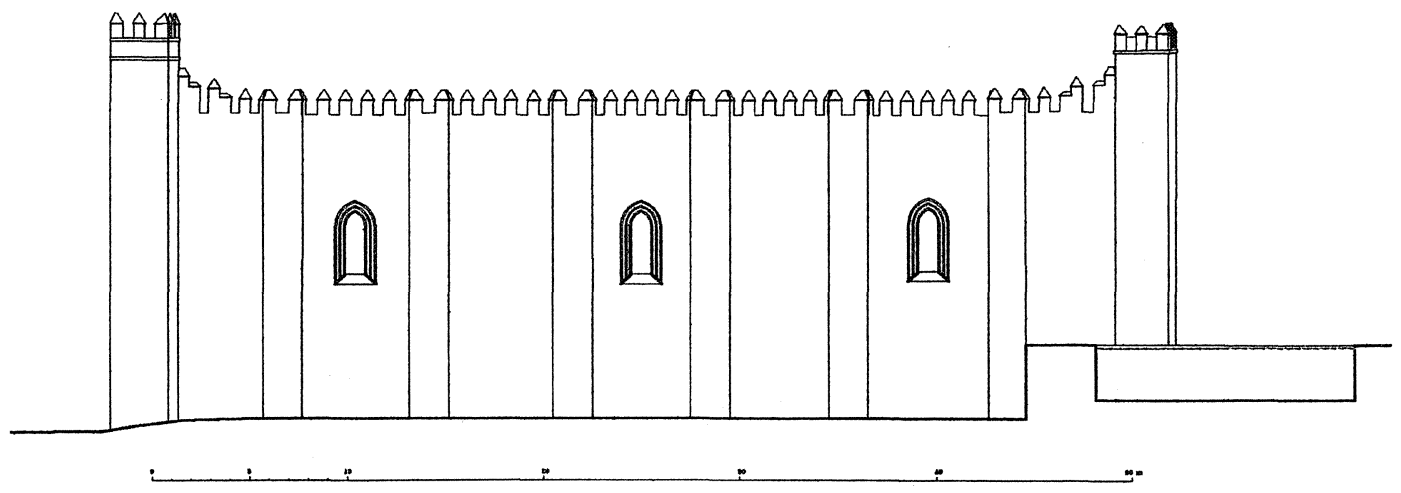

Figura 11. Alzado sur del palacio alfonsí. 
AQ. XX, 1999

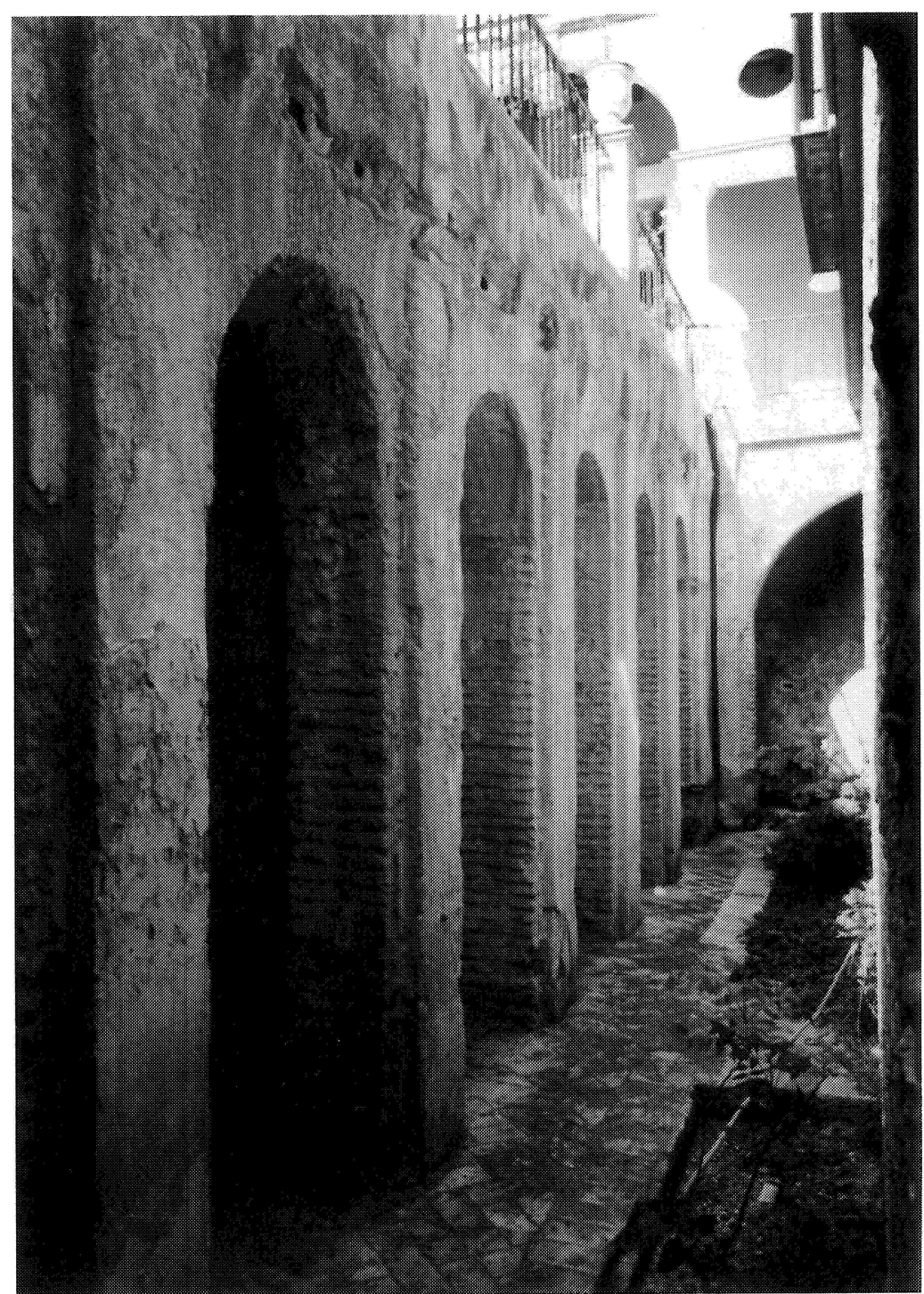

Lámina 1. Galería norte del pórtico inferior. 


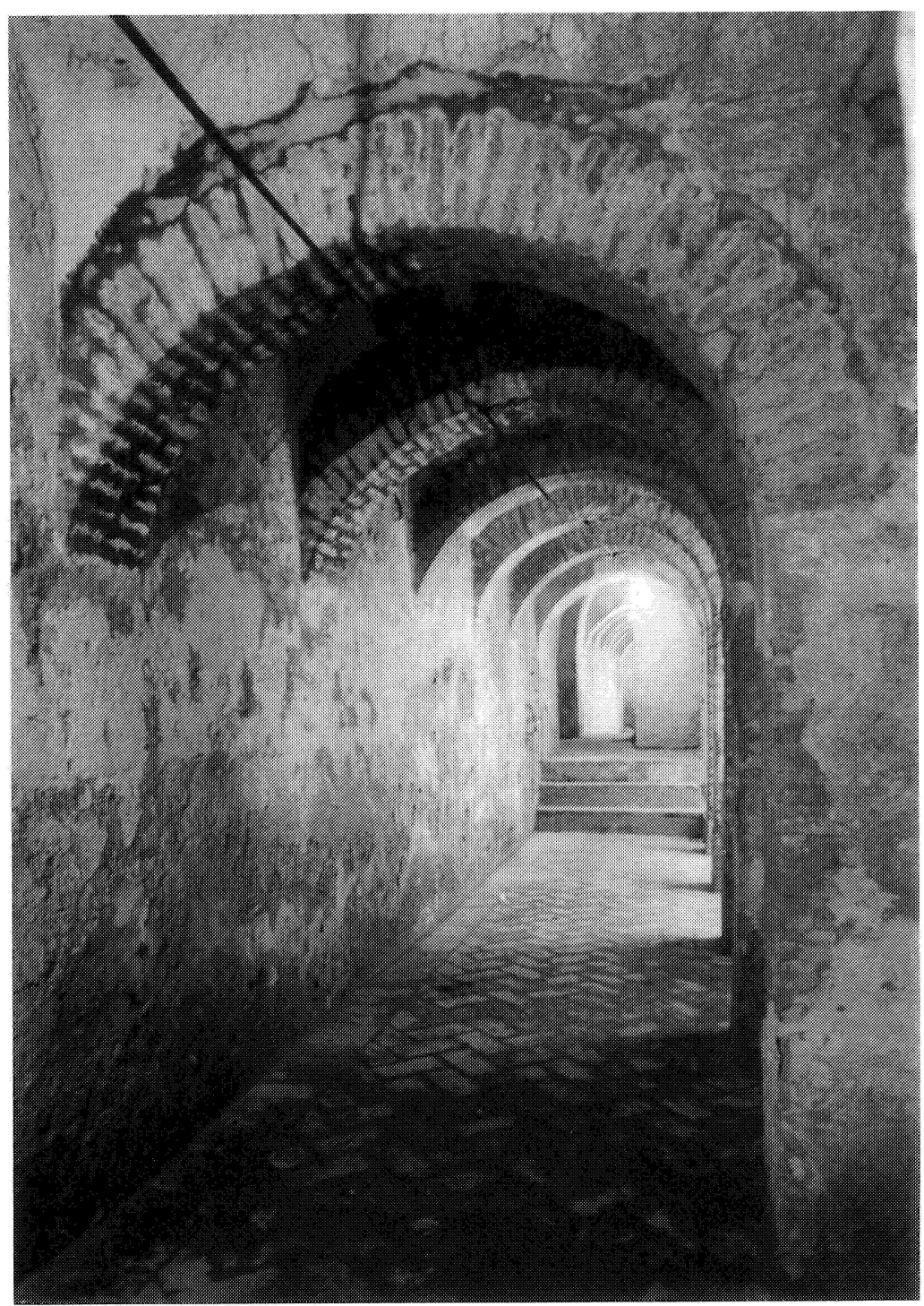

Lámina 2. Interior de la galería norte. 


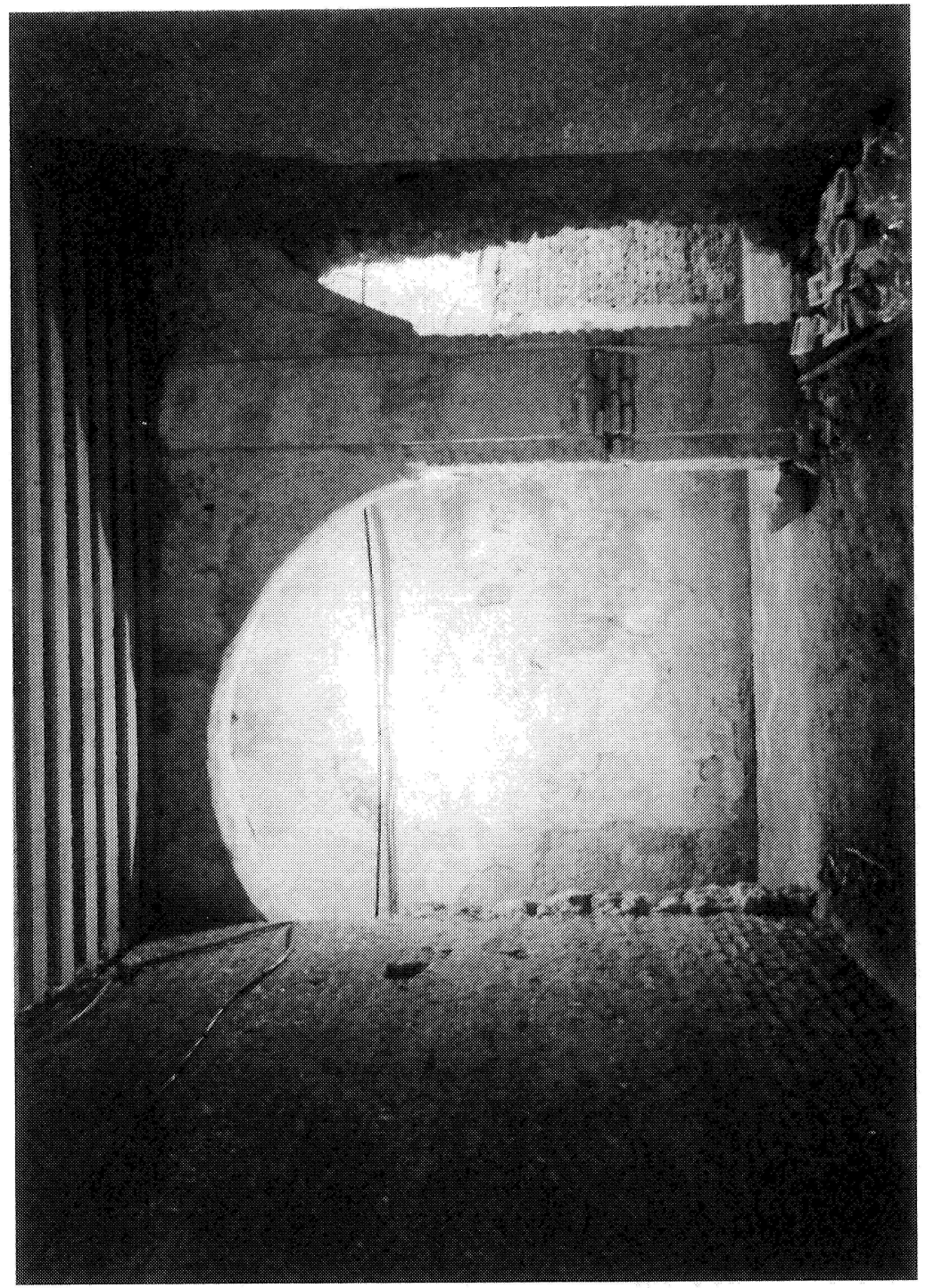




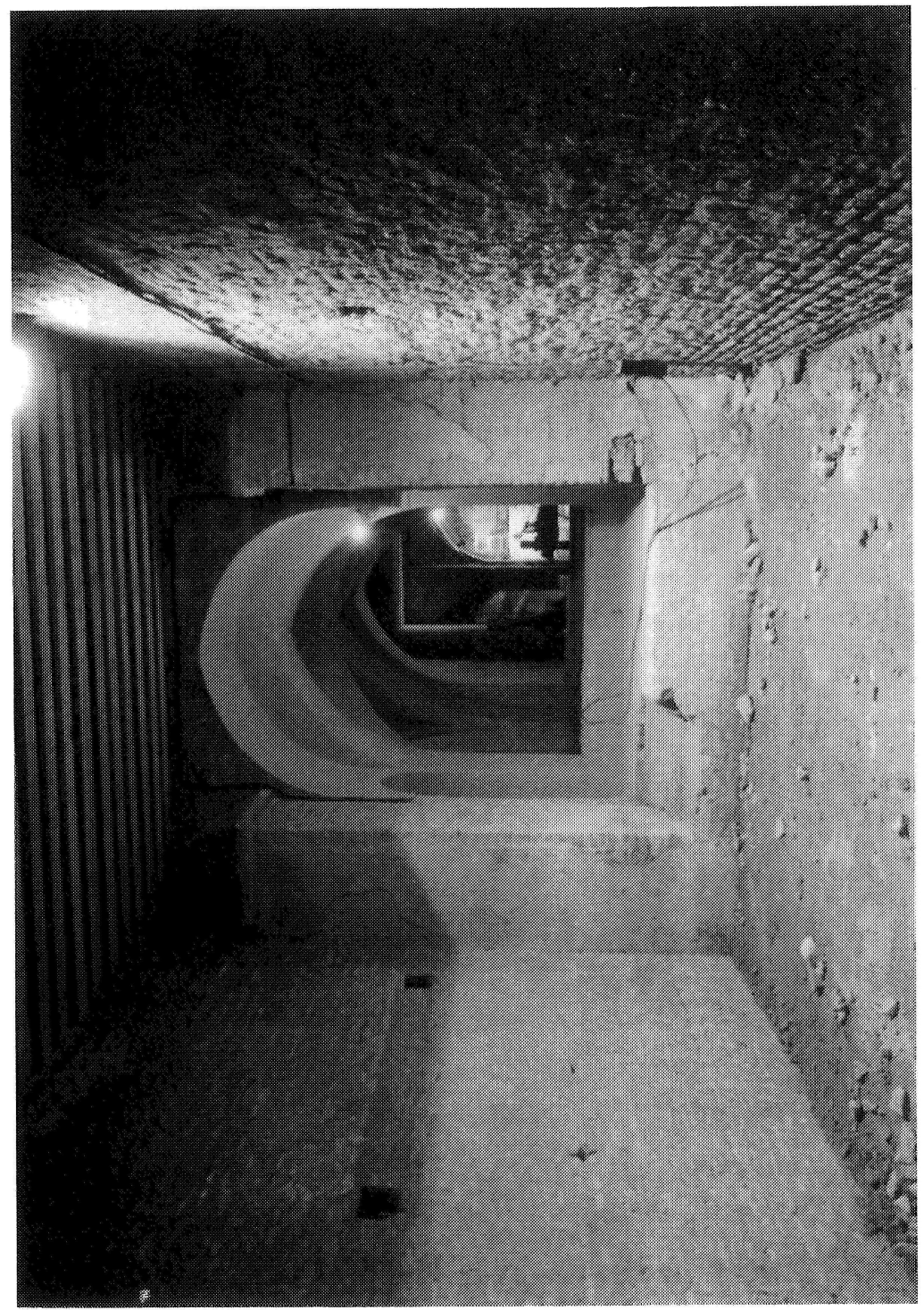




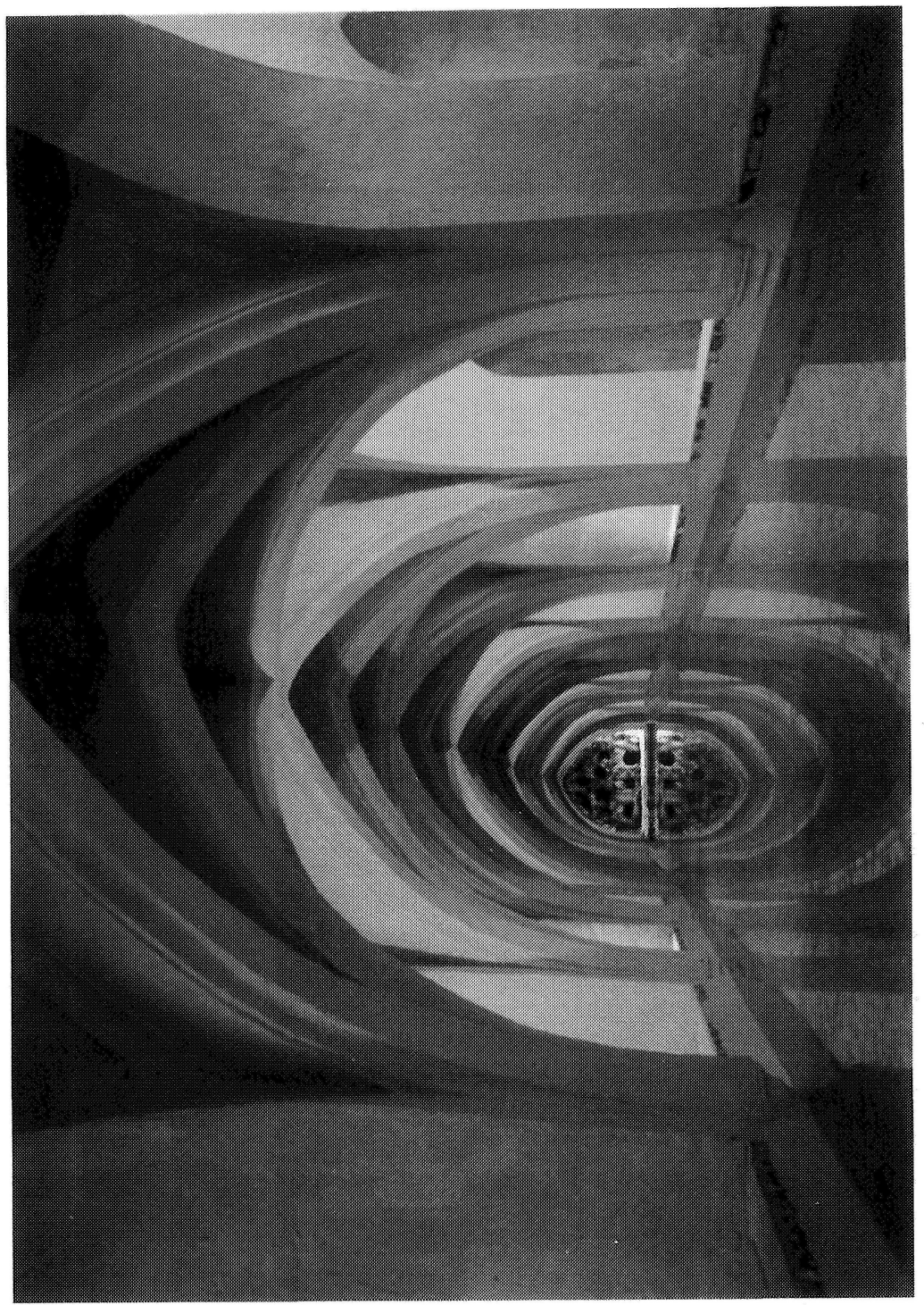




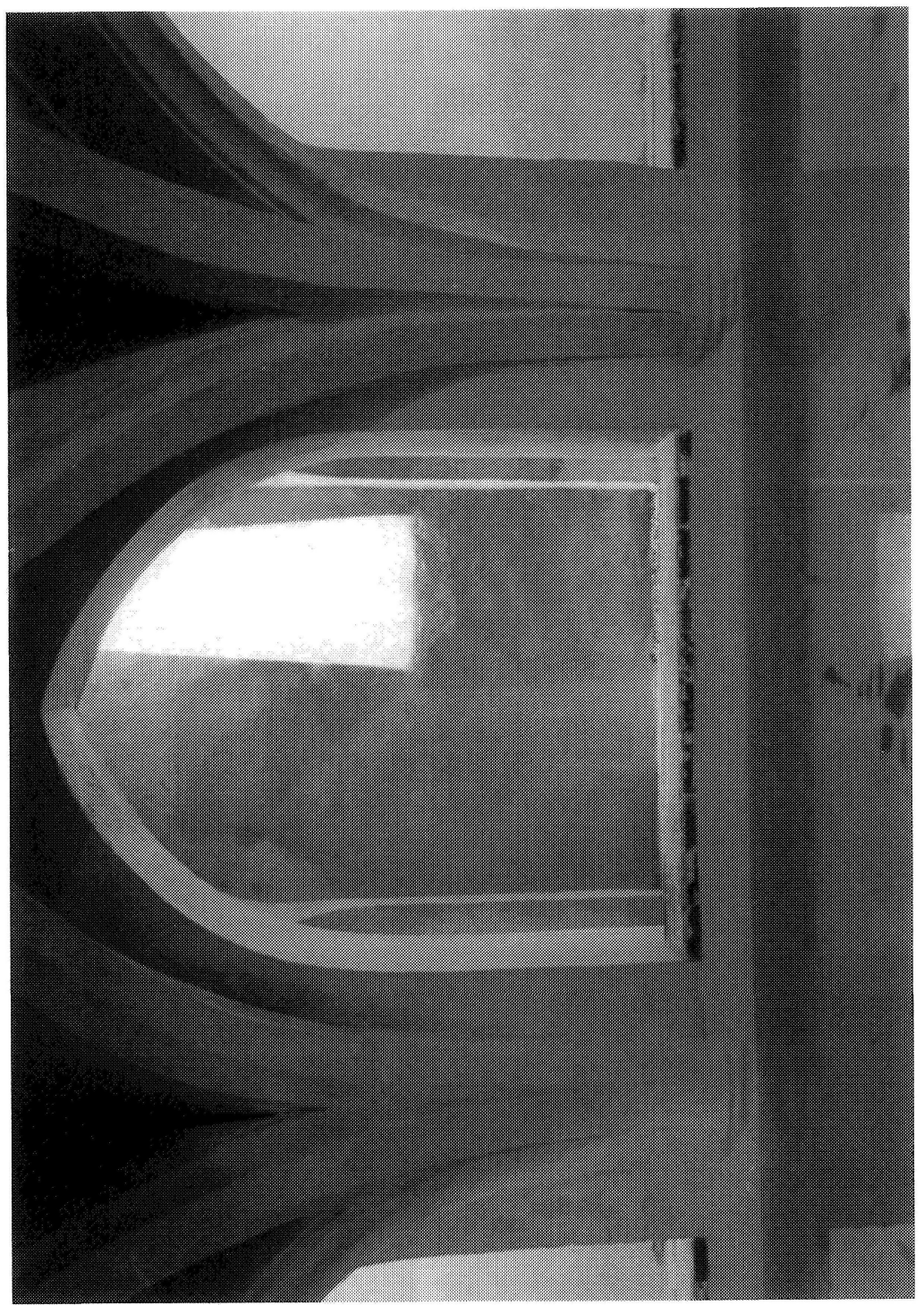




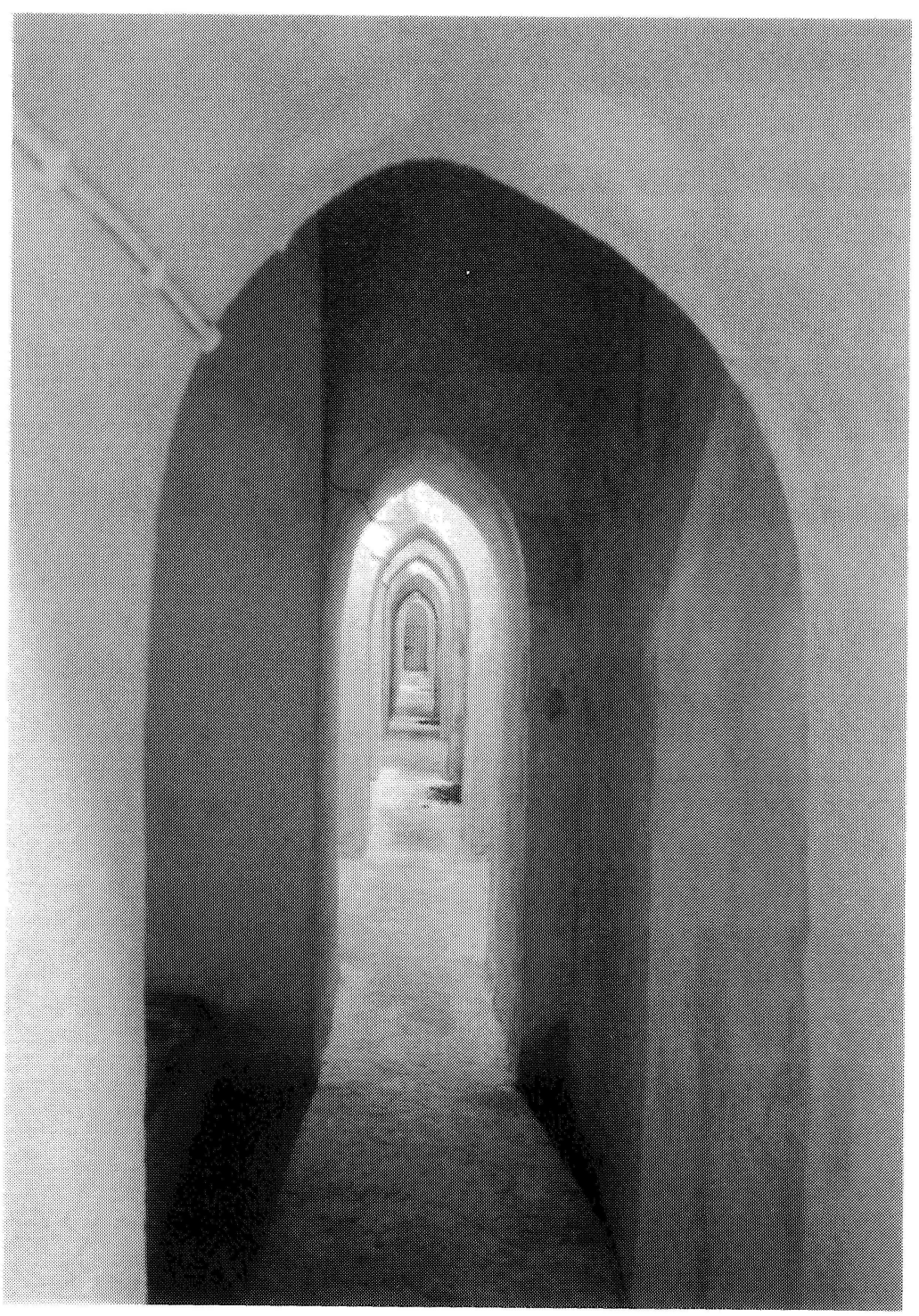

Lámina 7. Pasaje lateral del pórtico central alfonsí. 


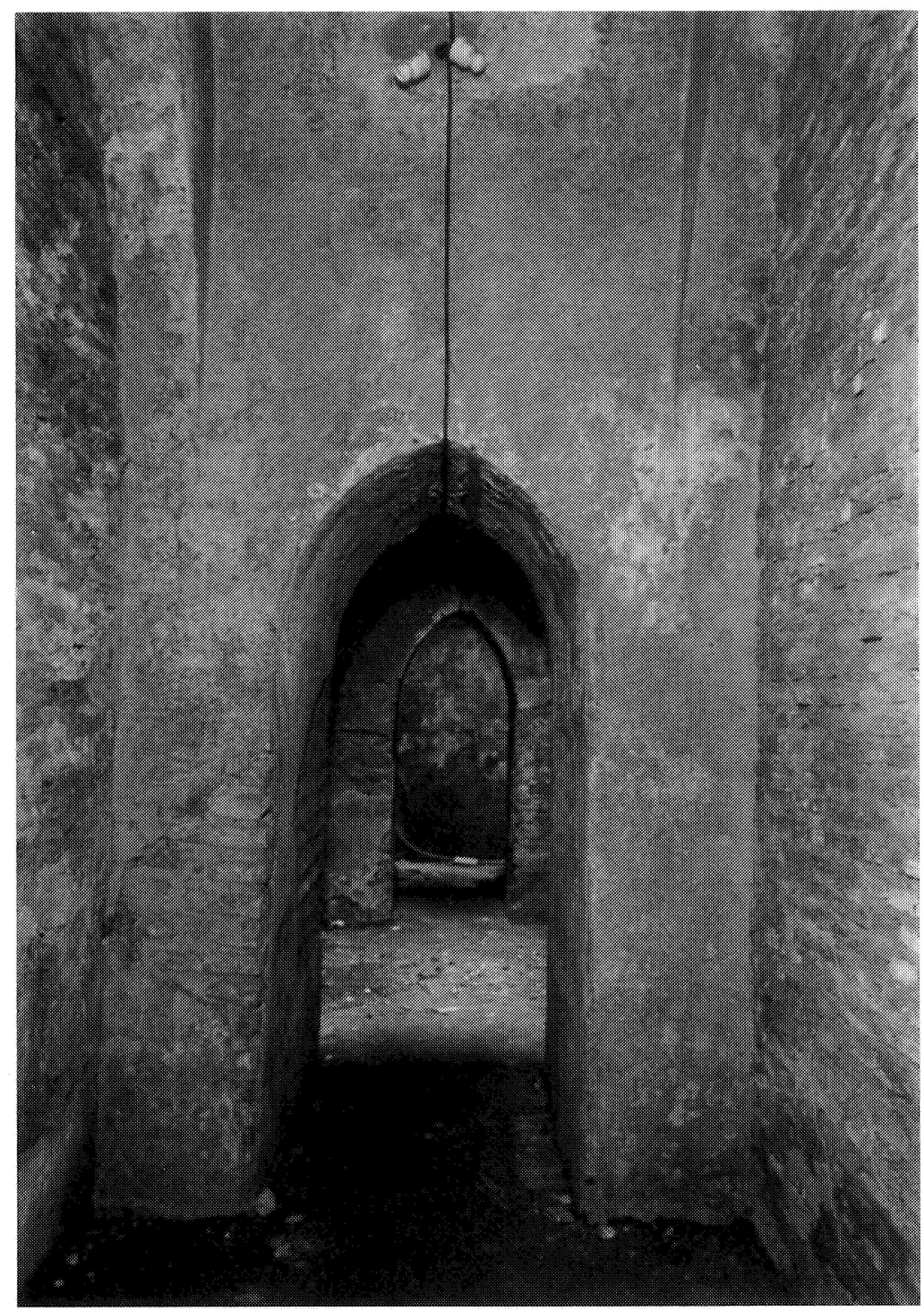

Lámina 8. Pasaje inferior del crucero. 


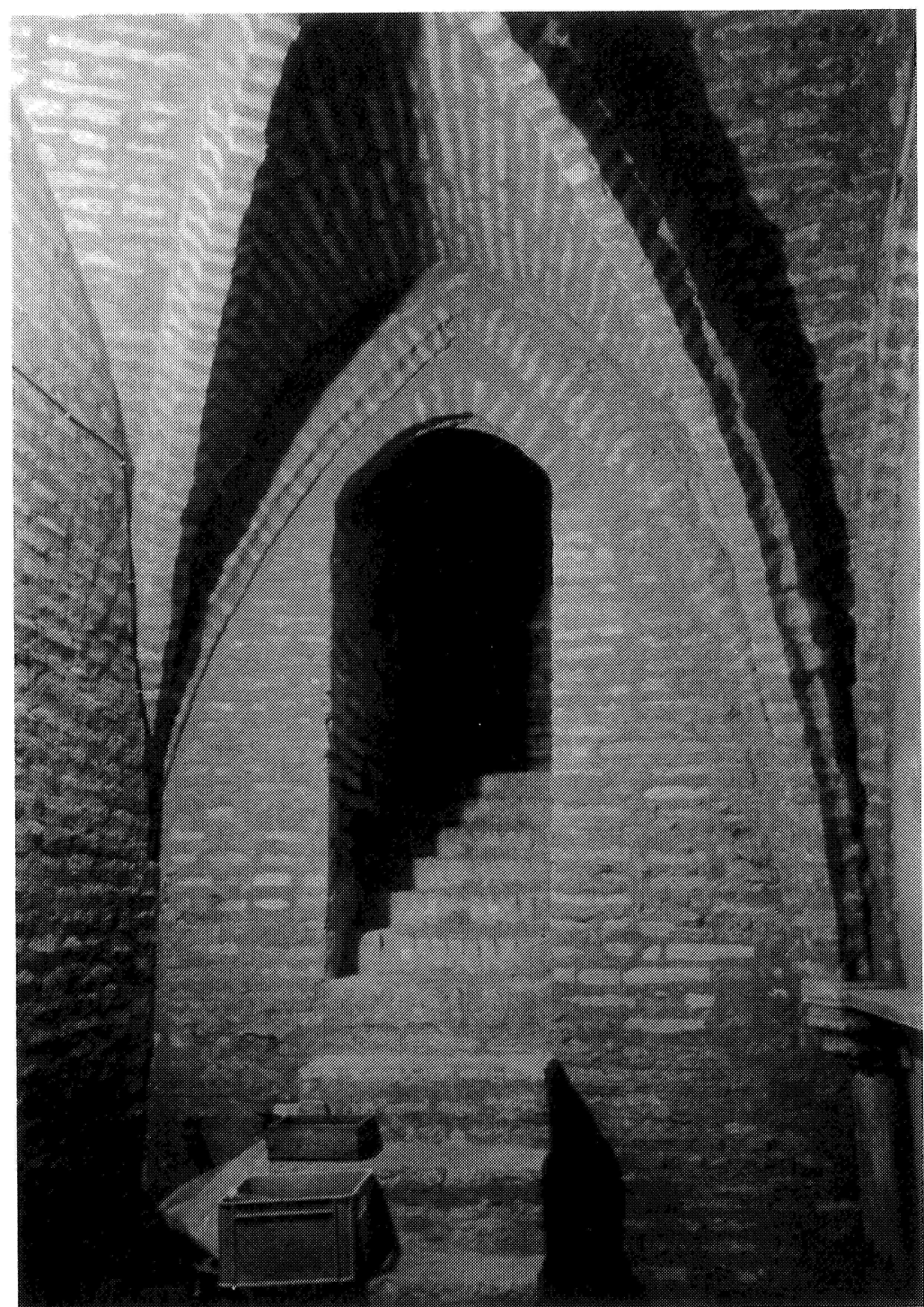

Lámina 9. Escalera de bajada al nivel del jardín en el extremo occidental del pórtico gótico meridional. 


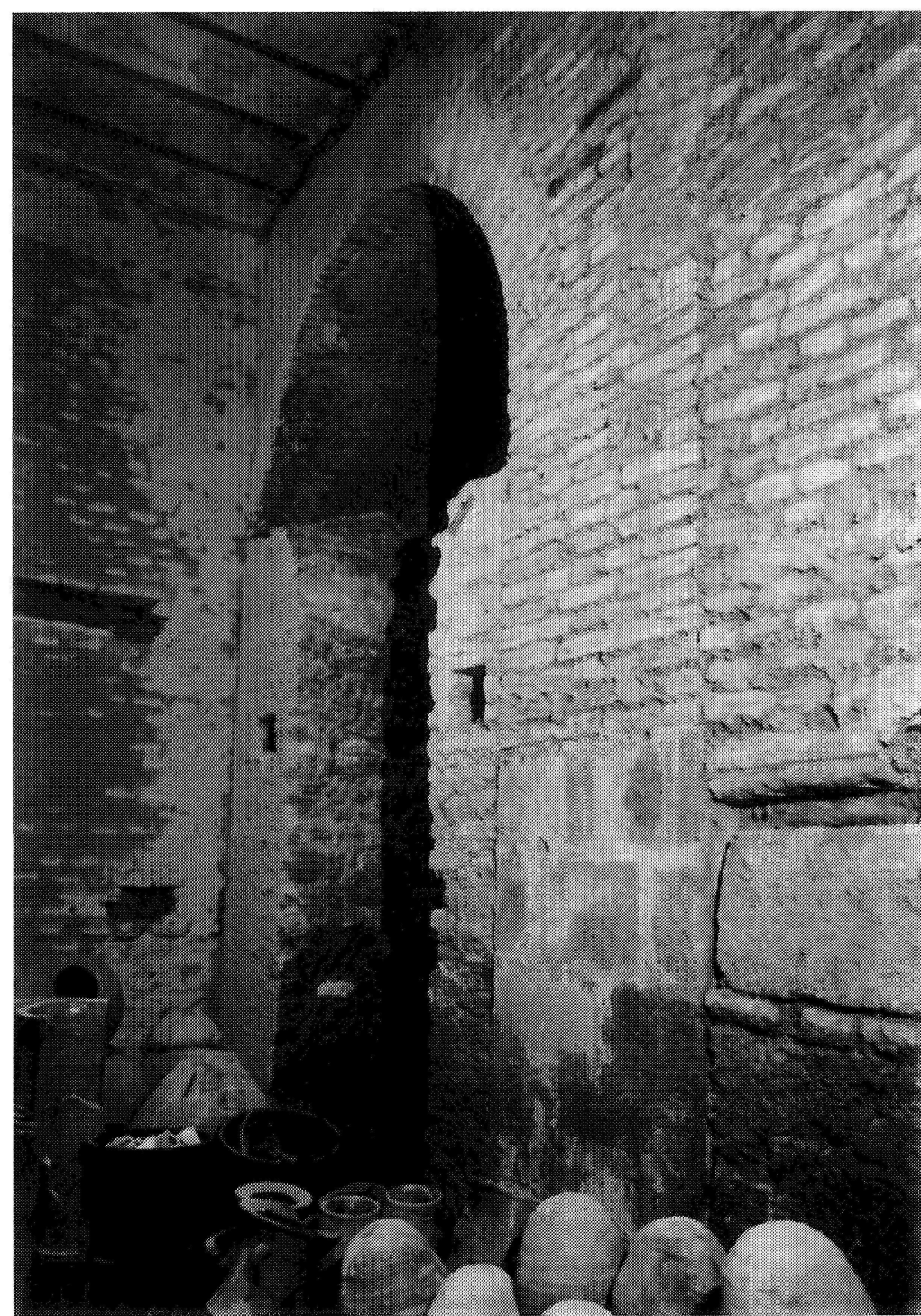

Lámina 10. Arcos y muro de refuerzo en la cimentación del pórtico barroco. 